\title{
CAN RELIGION WITHOUT GOD LEAD TO RELIGIOUS LIBERTY WITHOUT CONFLICT?**
}

\author{
¿PUEDE RELIGIÓN SIN DIOS CONDUCIR \\ A LA LIBERTAD RELIGIOSA SIN CONFLICTO?
}

\author{
Linda C. MCCLAIN ${ }^{* *}$
}

\section{Resumen:}

Este artículo discute el último libro de Dworkin, Religión sin Dios, el cual propone disminuir la importancia de la feroz "guerra cultural" en los Estados Unidos entre creyentes y no creyentes al separar el componente "científico" y de "valor" de la religión y demostrar que los involucrados en la guerra comparten un "impulso religioso fundamental". En el libro Religión sin Dios Dworkin también sostiene la necesidad de ubicar la libertad religiosa como parte de un derecho general de independencia ética, más que en un derecho especial para la gente religiosa, lo cual solo gene-

* Artículo recibido el 14 de septiembre de 2014 y aceptado para su publicación el 24 de septiembre de 2014.

** Professor of Law and Paul M. Siskind Research Scholar, Boston University School of Law. I presented a draft of this Article at the Conferencia Internacional, Ronald M. Dworkin, UNAM, Mexico City, February 13-14, 2014. I am grateful to Imer B. Flores, organizer of that event, and to Itzel Mayans for her incisive commentary. Thanks also to Jim Fleming for constructive editorial and substantive comments, and to M. Christian Green for raising many insightful questions, some of which I must save for future exploration. Thanks as always to Stefanie Weigmann, Assistant Director for Research, Faculty Assistance, and Technology, Pappas Law Library, for valuable research assistance. This Article previously appeared in the Boston University Law Review, Volume 94, Number 3 (July 2014), and is published here with permission. Thanks to my research assistant for editorial help in preparing it for publication.

This article is published with the authorization of its author and Boston University Law Review. 
Este libro forma parte del acervo de la Biblioteca Jurídica Virtual del Instituto de Investigaciones Jurídicas de la UNAM

\title{
LINDA C. McCLAIN
}

ra confusiones y problemas. Comparo la estrategia argumentativa de Dworkin en Religión sin Dios con trabajos previos como Life's Dominion y Is Democracy Possible Here? en donde también se atienden debates entre gente polarizada en Guerra, debates como el aborto y la ubicación de la religión en la vida pública, donde Dworkin de nuevo argumenta la necesidad de disipar confusiones intelectuales para saber de manera clara qué está realmente en discusión, para así lograr un cese al fuego o por lo menos una reducción de las hostilidades y el conflicto. También en esta colaboración resalto cómo Dworkin, en Religión sin Dios al apelar a lo estético a lo científico y a los desfios de vivir bien, incorpora características de su filosofía del liberalismo ético defendida más claramente en Justicia para Erizos pero que data de Foundations of Liberal Equality. Finalmente me pregunto qué tan exitosos son los argumentos de Dworkin como filósofo de la religión y si este nuevo marco constitucional que ofrece, realmente disminuye los conflictos sobre la libertad religiosa. O como lo sostienen algunos críticos, me preguntaré si Dworkin hace que la religión sea algo aceptable para los liberales y el liberalismo de una manera que la marginaliza o elimina sus rasgos principales. Dado que las discusiones contemporáneas sobre el matrimonio entre personas del mismo sexo constituyen una prueba importante, compararé el enfoque de Dworkin basado en el derecho a una independencia ética, con el de teóricos del derecho natural como Robert P. George y sus co-autores Ryan Anderson y Sherif Girgis.

\section{Palabras clave:}

Ronald Dworkin, liberalismo, religión, libertad religiosa, matrimonio, ateísmo, ética.

\begin{abstract}
:
This Article engages with Ronald Dworkin's final book, Religion without God, which proposes to shrink the size and importance of the fierce "culture wars" in the United States between believers and nonbelievers - theists and atheists - by separating out the "science" and "value" components of religion to show these groups that they share a "fundamental religious impulse." Religion without God also calls for framing religious freedom as part of a general right to ethical independence rather than a "troublesome" special right for religious people. This article compares the argumentative strategy of Religion Without God with prior Dworkin works, such as Life's Dominion and Is Democracy Possible Here?, which tackle a polarizing issue where parties are at "war" —such as abortion rights or the place of reli-
\end{abstract}


Este libro forma parte del acervo de la Biblioteca Jurídica Virtual del Instituto de Investigaciones Jurídicas de la UNAM

\section{CAN RELIGION WITHOUT GOD LEAD TO RELIGIOUS LIBERTY?}

gion in public life- and submits that, by dispelling intellectual confusion and offering a fresh understanding of what is really at issue, they may be able to have a ceasefire or, at least, a substantial reduction of hostility and conflict. The article also highlights how Religion without God, with its appeal to the aesthetic and the scientific and to the challenge of living well, incorporates characteristic features of Dworkin's philosophy of ethical liberalism, articulated most fully in Justice for Hedgehogs but dating back at least to Foundations of Liberal Equality. Finally, the article asks how persuasive Dworkin is as a theologian or philosopher of religion and whether the new constitutional frame he offers will help to reduce conflicts over religious liberty. Or, as some critics assert, does Dworkin make religion safe for liberals and liberalism in a way that denudes or marginalizes it? Because the current controversy over same-sex marriage is a particularly significant test case, I compare Dworkin's approach, centered on a right to ethical independence, with that of natural law theorist Robert P. George and his co-authors Ryan Anderson and Sherif Girgis.

Keywords:

Ronald Dworkin, Liberalism, Religion, Religious Liberty, Marriage, Atheism, Ethics. 
SUMmARY: I. Introduction. II. 'Once More unto the Breach, Dear Friends': Dworkin Tackles another Culture War. III. Religion without God as a Form of Ethical Liberalism. IV. Will Dworkin's 'Prayer' Be Answered?: Can His Religion Without God Reduce Conflict Over Religious Liberty? V. Conclusion. VI. Bibliography.

\section{INTRODUCTION}

This Article engages with Ronald Dworkin's final book, Religion without God, approaching this elegant, even elegiac work from several angles. First, in Part I, I compare the argumentative strategy of Religion without God $^{1}$ with that of Dworkin's prior books, Life's Dominion ${ }^{2}$ and Is Democracy Possible Here? ${ }^{3}$. In these books, he tackles a polarizing issue where parties are at 'war' and proposes that, by dispelling 'intellectual confusion'4 and offering a fresh understanding of what is really at issue, they may be able to have a ceasefire or, at least, a substantial reduction of hostility and conflict. So, too, in Religion without God, Dworkin takes on the seemingly 'wholly unbridgeable gap's between 'believers and nonbelievers' in 'the new religious wars' in politics ${ }^{6}$. He argues that '[i]f we can separate God from religion', this new understanding of 'what the religious point of view really is' has the potential to 'shrink both the size and importance of the wars', so that they would no longer be 'culture wars', or to 'lower, at least, the temperature of these battles'? Further, by framing religious freedom around protect-

1 Ronald Dworkin, Religion withou God, (HUP 2013).

2 Ronald Dworkin, Life's Dominion an argument about abortion, euthanasia, and individual freedom, (Knopf 1993).

3 Ronald Dworkin, Is Democracy Possible Here?: principles for a new political debate. (PUP 2006) 1-2.

4 Ronald Dworkin, Life's Dominion (n 2) 4.

5 Dworkin, (n 1) 147.

6 Ibid 137.

7 Ibid 9. 
ing a 'general right to ethical independence' rather than a 'troublesome special right' for theistic religious people, Dworkin's argument calls for a 'radical reinterpretation of all the constitutions, [human rights] conventions, and human rights covenants's. In all three works, the new understanding Dworkin urges rests on principles about dignity, responsibility, and the intrinsic value of human life, with implications for limitations upon governmental authority.

In Part II, I hone in on how Dworkin's project in Religion without God of offering an account of religion that reveals underlying convictions that unite theists and 'religious atheists'9 incorporates characteristic features of Dworkin's philosophy of ethical liberalism, articulated fully in his majestic Justice for Hedgehogs ${ }^{10}$. Ethical liberalism, which dates back at least to Dworkin's Foundations of Liberal Equality, appeals to convictions about dignity, responsibility, the challenge of living life well, the objectivity of values, and life's intrinsic value (Dworkin 1990). Another characteristic feature is the turn to the aesthetic - to artistic creation - to articulate the idea of living life well and making a success of one's life ${ }^{11}$. So, too, Religion without God reveals Dworkin's continued fascination with the scientific learning of the day, tracing out themes of beauty, inevitability, objectivity of value (once again), and integrity ${ }^{12}$.

In Part III, I ask how persuasive Dworkin is as a theologian or philosopher of religion. Specifically, is his new ac-

8 Ibid 133.

9 Ibid 12.

10 Ronald Dworkin, Justice for Hedgehogs (Belknap Press 2011) 13-14 argues for the sovereign ethical responsibility to make something of value of our lives by analogy to artistic creation, and argues further that "we must treat the making of our lives as a challenge, one we can perform well or badly'.

11 Dworkin, (n 1) 157-158.

12 Ibid 45-104. Nearly three decades ago, in Law's Empire, Dworkin (1986, p. 183) analogized to astronomy, explaining that '[a]stronomers postulated Neptune before they discovered it', and arguing that '[i]ntegrity is our Neptune'. 
count of religion and religious freedom, as he hopes and prays ${ }^{13}$, likely to 'shrink both the size and the importance of' the fierce 'culture wars' in the United States between believers and nonbelievers - theists and atheists - by showing these groups that they 'share a fundamental religious impulse'14? Will the new constitutional frame he offers -ethical independence rather than a special right for theists - help to reduce conflicts over religious liberty? In short: Is what constitutional law scholar Laurence Tribe recently referred to as Dworkin's 'sunny assumption that reason would dissolve the deepest differences underlying our legal and especially our constitutional outlooks' warranted ${ }^{15}$ ?

I consider several lines of criticism that 'believers' might direct at both components of Dworkin's project: his identification of the 'religious attitude'16 that can exist apart from a belief in a 'personal god'17 and his 'radical reinterpretation'18 of religious freedom for purposes of constitutional jurisprudence. I use as one foil the account of religion and religious freedom developed in Robert P. George's recent book of essays, Conscience and Its Enemies: Confronting the Dogmas of Liberal Secularism. Is Dworkin, as some critics assert, making religion safe for liberals and liberalism ${ }^{19}$ in a

13 Ibid 146-147.

14 Ibid 146.

15 Ibid 510.

16 Ibid 9.

17 Ibid 33.

18 Ibid 133.

19 Fish 'Deeper than God: Ronald Dworkin's religious atheism', New York Times, (USA 23 September 2013), , http://opinionator.blogs.nytimes. com/2013/09/23/deeper-than-god-ronald-dworkins-religious-atheism accessed 21 May 2014. Argues that Dworkin's book is 'speaking . . . to liberals' and is consonant with liberalism's reducing religion to a form that is 'perfectly acceptable to liberalism because it is liberalism'. 
way that denudes or marginalizes it20? The current controversy over the definition of marriage is a particularly significant test case for Dworkin's proposed recasting of religious freedom as ethical independence, and here, too, George provides a useful counter approach. I ask how Dworkin's framework would address claims brought by believers and religious institutions that these developments in civil law (1) reflect an erroneous understanding of the truth of marriage, and (2) deeply threaten religious freedom by establishing a new governmental orthodoxy hostile to traditional religious belief.

\section{II. 'ONCE MORE UNTO THE BREACH, DEAR FRIENDS':21 DWORKIN TACKLES ANOTHER CUlture WAR}

In this Section, I briefly explicate Dworkin's argument in Religion without God about the religious attitude, pointing out how it takes further certain ideas articulated in Justice for Hedgehogs. I then point out similarities between Religion without God and prior works by Dworkin offering an intervention into a polarizing issue where parties are, as it were, at war, namely, Life's Dominion and Is Democracy Possible Here? In each instance, Dworkin takes on a seemingly 'unbridgeable' divide and reveals that a clearer understanding of what is at stake offers a way out ${ }^{22}$. Not only is the method similar in each instance, but so too is the substantive content of the principles around which reconciliation is possible. Thus, the 'religious attitude' that, Religion without God contends, unites rather than divides believers and

20 Movsesian (2013) relates Dworkin's argument against the special status of religion to the left's efforts to 'continue to marginalize traditional religion'. For additional criticisms along these lines, see infra Part III.

21 Apologies to Dworkin and to Shakespeare (Henry V, act 3, scene 1) for the questionable aptness of this line. I had King Henry V's rousing speech on my mind after recently watching a stunning new version of Henry V in the Hollow Crown series (2012).

22 Dworkin, (n 1) 147. 
nonbelievers resonates with key principles identified in these two earlier works and carried further in Justice for Hedgehogs, as I discuss in Part II.

\section{Religion Without God: Identifying the Shared Religious Impulse}

In Religion without God, Dworkin expresses a 'a hope; indeed,... a prayer', that if people come to understand that they 'share a fundamental religious impulse that has manifested itself in various convictions and emotions', theists and atheists 'may come to accept that what they now take to be a wholly unbridgeable gap is only an esoteric kind of scientific disagreement with no moral or political implications'23. For 'the new religious wars', he contends, 'are now really culture wars... not just about scientific history' - for example, intelligent design versus evolution- 'but more fundamentally about the meaning of human life and what living well means'24. That religious impulse, Dworkin argues, historically has included two distinct kinds of convictions: 'A] belief in an intelligent supernatural force -a god- and a set of profound ethical and moral convictions'25. Dworkin speaks of these, respectively, as the 'science' part of religion and the 'value' part; he argues that, even though historically they have traveled together, they are 'conceptually independent' of one another ${ }^{26}$. Thus, an atheist can have 'Religion without God' if he or she has a religious attitude toward the world. In Justice for Hedgehogs, Dworkin similarly refers to dividing religion into two parts: the 'cosmological' (that is, 'How did the world and its parts, including life and human life, come to exist?'), and the 'evaluative' (that is, questions about right and wrong, such

23 Ibid 146-147.

24 Ibid 9.

25 Ibid 146.

26 Ibid 24-25. 
as 'What must I do with my life?' and 'How must I treat other people?') 27.

In a sense, this religious attitude -with its two-pronged focus on science and value- carries forward the project expressed in the final pages of Justice for Hedgehogs, where Dworkin calls for a 'postcolonial conception of truth', insisting that evaluative judgments about truth and what makes life go well need not hinge on physics ${ }^{28}$. There, Dworkin decries how modern philosophers have 'inflated the methods of physics into a totalitarian metaphysics', raising concerns about how to 'test' judgments about value ${ }^{29}$. Dworkin, however, counters that a postcolonial conception would affirm 'the profound independence of morality, ethics, and other forms of value'; rather than seeking to 'certify' the truth of our value judgments through scientific or metaphysical discoveries, we instead 'must make a case, not supply evidence, for our convictions'30.

In Religion without God, Dworkin's postcolonial conception of truth affirms the independence of the 'science' and 'value' parts of religion, but links them in a certain 'religious' orientation toward the world. The religious attitude, he argues, 'accepts the full, independent reality of value' and 'the objective truth of two central judgments about value'31. The first judgment 'holds that human life has objective meaning or importance', so that '[e]ach person has an innate and inescapable responsibility to try to make his life a successful one'32. Dworkin elaborates: '[T]hat means living well, accepting ethical responsibilities to oneself as well as moral responsibilities to others, not just if we happen to think this important but because it is in itself impor-

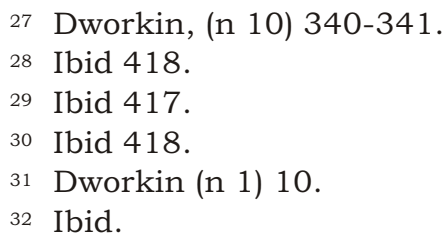


tant whether we think so or not'33. The second judgment "holds that what we call "nature"-the universe as a whole and in all its parts-is not just a matter of fact but is itself sublime: something of intrinsic value and wonder' (2013, p. $10)^{34}$. 'Together these two... value judgments', Dworkin argues, are 'comprehensive' and 'declare inherent value in both dimensions of human life: biological and biographical'35.

I focus more on Dworkin's arguments about 'the value part' of religion than 'the science part', since the former are more pertinent to his argument for reconceiving religious freedom. The 'value part' of conventional theistic religions, such as Judaism, Christianity, and Islam, Dworkin contends, 'offers a variety of convictions about how people should live and what they should value'36. Some of those convictions, what he calls 'godly commitments', are 'parasitic' on a belief about a personal god and 'declare duties of worship, prayer, and obedience to the god the religion endorses'37. (I return to potential problems with Dworkin's inclusion of 'obedience' in this 'godly' part later in this Article.) Other 'religious values', Dworkin continues, are not 'parasitic' in this way and so are 'independent' of that 'assumption of a god'38. Indeed, he contends, the two 'paradigm religious values' he identifies 'are in that way independent', and can unite believers and religious atheists even though the latter 'do not believe in a god and so reject the science of conventional religions and the godly commit-

33 Ibid.

34 Ibid. In his review, Moshe Halbertal (2013) observes that Dworkin's rejection of naturalism, evident both in his insistence on the objective foundation for our values and his argument that the universe is genuinely enchanted', runs 'against much of contemporary. For a critique that Dworkin's account of naturalism rests on stereotyped views of naturalists, see Charles Murn (2013).).

$\begin{array}{ll}35 & \text { Ibid } 11 . \\ 36 & \text { Ibid } 23 . \\ 37 & \text { Ibid } 24 . \\ 38 & \text { Ibid. }\end{array}$ 
ments, like a duty of ritual worship'39. For religious atheists 'accept that it matters objectively how a human life goes and that everyone has an innate, inalienable ethical responsibility to try to live as well as possible in his circumstances'40. And, turning to the second 'paradigm value', religious atheists 'accept that nature is not just a matter of particulars thrown together in a very long history but something of intrinsic wonder and beauty' 41 .

\section{Life's Dominion: Shared Intuitions about the Sanctity of Life}

Dworkin's intervention into the 'culture wars' over religion has parallels with his earlier interventions into forms of 'religious' or 'culture' war over abortion. In Life's Dominion, Dworkin argued that the contemporary battle over abortion rights is 'America's new version of the terrible seventeenth-century European civil wars of religion'42. He also argued that one reason the battle over religion has seemed 'fiercer and more violent in America than anywhere else' is because of 'the peculiar paradox of America's ambivalence toward religion': formal separation, under the U.S. Constitution, of church and state, but a populace that is 'among the most religious of modern Western countries', and that includes fundamentalist groups among 'the most powerful religious groups' 43 . He submitted that 'the character of the abortion argument is wrong'44. Dworkin argued that 'the standard view of the character of the abortion argument'

39 Ibid.

40 Ibid.

41 Ibid. In Part III, I consider whether this account of religion is likely to be persuasive to conservative religious theorists and what potential it holds for ongoing controversies about religious liberty and the place of religion in public life.

42 Dworkin (n 2) 4.

43 Ibid 6.

44 Ibid 10-11. 
framed it around the 'polarizing question' of whether a fetus is 'a helpless unborn child with rights and interests of its own from the moment of conception', such that 'permitting abortion is permitting murder'45. Analogizing to slavery, apartheid, and rape, Dworkin argued that '[s]elf-respecting people' who answered that question differently could hardly be expected to 'compromise'46. Dworkin submitted that this conventional and polarizing framing reflected 'widespread intellectual confusion' that 'we can identify and dispel', allowing a 'responsible legal settlement of the controversy' that everyone 'can accept with full self-respect' 47 .

That settlement would rest on a new understanding: that people share certain intuitions about the sanctity of life that life is sacred and has intrinsic value, and that it is important that a life, once begun, go well rather than be wasted. What divides them, then, is how best to respect a fundamental idea we almost all share in some form: that individual human life is sacred'48. Dworkin ${ }^{49}$ appealed to nature and to art to explain these intuitions, a characteristic feature of his work. He clarified that his argument accepted the U.S. Supreme Court's decision that a fetus is not a constitutional person 'with rights and interests of its own', and instead framed the issue in terms of what governmental regulation is permissible to express respect for 'the sanctity of human life'50.

Dworkin translated his philosophical argument into an account of constitutionally permissible —and impermissible- governmental regulation ${ }^{51}$. As I address elsewhere (individually and with James Fleming), Dworkin distinguishes between government insisting upon (that is, coercing) con-

45 Ibid 9.

46 Ibid 10.

47 Ibid 10-11.

48 Ibid 13.

49 Ibid 71-81.

50 Ibid 161.

51 Ibid 160-168. 
Este libro forma parte del acervo de la Biblioteca Jurídica Virtual del Instituto de Investigaciones Jurídicas de la UNAM

formity and encouraging responsibility: government may not compel a woman's abortion decision to further its view about sanctity, but it may regulate in ways that encourage her to 'treat the question of abortion seriously', because it is a decision implicating the intrinsic value of the sanctity of life ${ }^{52}$. Dworkin also showed how his distinction between the governmental goals of conformity and responsibility mapped well onto the joint opinion's analysis in Planned Parenthood of Southeastern Pennsylvania v. Casey [1992] 505 U.S. 833.53 That argument is not my focus here; instead, what is striking in light of Religion without God is Dworkin's argument in Life's Dominion that, among the 'textual homes' for the right of procreative autonomy is the First Amendment, because 'the First Amendment forbids states to force people to conform to an official view about what the sanctity of human life requires'54. The gist of his argument is: 'If people's convictions about what the inherent value of human life requires are religious convictions, a

52 James Fleming and Linda McClain, Ordered liberty: rights, responsabilities, and virtues, (HUP 2013) 50-58. I evaluate Dworkin's analysis in several works: James E. Fleming and I (2013) contrast Dworkin's approach with Mary Ann Glendon's to suggest a distinction between responsibility as autonomy and responsibility as accountability; I (McClain 2006) discuss Dworkin's distinction between conformity and responsibility favorably and agreeing that government, 'consistent with respect for constitutional liberty, may encourage the goal of 'responsibility' in the sense of reflective decision making' (p. 228); and I (McClain 1998) support Dworkin's distinction between conformity and responsibility, but raising questions about governmental persuasion in the context of women's abortion decisions (pp. 91-100).

53 The Court in Casey [1992] 505 U.S. 883 states, 'What is at stake is the woman's right to make the ultimate decision, not a right to be insulated from all others in doing so' (at 877), and as such, 'states are free to enact laws to provide a reasonable framework for a woman to make a decision that has such profound and lasting meaning' (p. 916). Dworkin (1993, pp. 152-153) quotes the Casey joint opinion as articulating the state's 'legitimate interest in encouraging responsibility'. Dworkin (1993, p. 173) was critical of the Casey joint opinion's conclusion that the Pennsylvania statute did not constitute an undue burden.

54 Dworkin (n 2) 160-161. 
government's demand for conformity would be imposing a collective religion' (1993, p. 162) ${ }^{55}$ and would violate both the Free Exercise and Establishment Clauses of the First Amendment. Dworkin argues that the free exercise of religion should include a broad understanding of what 'religious' belief is ${ }^{56}$. He reiterates these arguments - sometimes incorporating them by reference- in Religion without God 57 .

In Life's Dominion, Dworkin points to Supreme Court precedents upholding conscientious objection to war as religious, even in the absence of a belief in a personal god 58 . He makes a point to which he returns in Religion without God: 'Once the idea of religion is separated from the idea of a god, however, courts that accept the constraints of integrity face great difficulty in distinguishing between religious and other kinds of conviction'59. Dworkin argues that one limiting principle is content. For example, Dworkin states: 'a belief in the objective and intrinsic importance of human life has a distinctly religious content'60. I quote in full his emphasis in Life's Dominion that religious belief or conviction need not presuppose a god:

Convictions that endorse the objective importance of human life speak to the same issues - about the place of an individual human life in an impersonal and infinite universe - as orthodox religious beliefs do for those who hold them.

I can think of no plausible account of the content that a belief must have in order to be deemed religious that would rule out convictions about why and how human life has intrinsic objective importance, except the abandoned notion that religious belief must presuppose a god. It is, of course,

55 Ibid 162.

56 Ibid 165.

57 Dworkin (n 1) 106-107, 120-124, 144-145.

58 Dworkin (n 2) 162.

59 Ibid.

60 Ibid 163. 
essential that any test of religious content distinguish between religious beliefs on the one hand and nonreligious political or moral convictions on the other. But we have already seen how the belief in life's intrinsic objective importance (and other beliefs that interpret and follow directly from that belief) differs from opinions about political fairness or the just distribution of economic or other resources ${ }^{61}$.

Dworkin then explains that 'the popular sense that the abortion issue is fundamentally a religious one' is 'at bottom sound', although 'for reasons somewhat more complex than is often supposed' 62 . Namely:

They rest on a natural —indeed, irresistible- understanding of the First Amendment: that a state has no business prescribing what people should think about the ultimate point and value of human life, about why human life has intrinsic importance, and about how that value is respected or dishonored in different circumstances ${ }^{63}$.

This does not mean 'every woman who decides to have an abortion broods first about why and how human life is sacred', but she may still 'act out of convictions that... presuppose views about that essentially religious issue'. Hence, 'a government that makes abortion a crime denies the free exercise of religion as much to such women as to women who do self-consciously draw their views about abortion from religious faith'64.

Dworkin concludes that the right to procreative autonomy, from which a right of choice about abortion flows, is well grounded in the First Amendment', as well as in 'the

61 Ibid 163-164.

62 Ibid 164.

63 Ibid 164-165.

64 Ibid 165. Dworkin continues that, even if a woman acts 'for some other reason that cannot be traced to even submerged views about the sanctity of life', her decision is still protected by the Due Process and Equal Protection Clauses of the Constitution (1993, p. 165). 
best interpretation of constitutional liberty and equality'65. Dworkin also grounds the right to procreative autonomy in 'Western political culture more generally', namely, in its 'belief in individual human dignity: that people have the moral right - and the moral responsibility - to confront the most fundamental questions about the meaning and value of their own lives for themselves, answering to their own consciences and convictions'66. Moreover, in a characteristic move, Dworkin argues that precisely because of our commitment to dignity, while we may and should care deeply about other people respecting 'the intrinsic value of human life', because their decisions shape the moral environment, we 'must insist on religious tolerance in this area'67. Dworkin 68 reiterates the essentially religious nature of the issue, enlisting some of the core tenets of his account of ethical liberalism:

Tolerance is a cost we must pay for our adventure in liberty. We are committed, by our love of liberty and dignity, to live in communities in which no group is thought clever or spiritual or numerous enough to decide essentially religious matters for everyone else. If we have genuine concern for the lives others lead, we will also accept that no life is a good one lived against the grain of conviction, that it does not help someone else's life but spoils it to force values upon him he cannot accept but can only bow before out of fear or prudence.

In Religion without God, Dworkin69 returns to his argument for a First Amendment grounding for the right to procreative autonomy. Acknowledging the problems with a concept of religion limited to theism, he contends that '[i]f... freedom of religion is not restricted to opinions about a god, but embraces all deep convictions about the purpose and

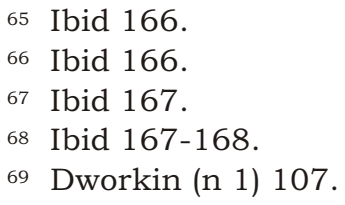


responsibilities of life, then it might be thought an open question whether the right to abortion is a religious issue'70. Certainly, "much of the opposition to abortion assumes that a god has forbidden that act'; but 'not all opposition is based on theism, and few women who want an abortion believe that a god has ordered them to abort'71. This idea of being 'ordered' to abort is an odd way to put the matter; many analyses of women's abortion decisions indicate that a woman's religious convictions play a role in her decision making to continue or terminate a pregnancy ${ }^{72}$. Moreover, different religious denominations vary in their ethical teachings about whether and when abortion is morally permissible; even within denominations opposing abortion rights, some dissenting voices argue for protecting 'a woman's moral and legal right to follow her conscience in matters of sexuality and reproductive health' (Catholics for Choice 2014, 'About us', para. 1). ${ }^{73}$ In other words, a subtler framing of Dworkin's argument could draw on a spectrum of conscientious religious views to suggest the 'essentially religious' nature of the issue for many people.

In any case, Dworkin revisits the abortion issue in Religion without God to contend that moving away from a special right to religious freedom to a more general right to ethical independence could help to make progress on the new religious wars' in American politics, in which 'sexual and reproductive morality' - including the right to abortion- is "undoubtedly the most divisive issue of all'74. He observes

70 Ibid.

71 Ibid.

72 Institute for Reproductive Health Access et al. 2007, p. 29.

73 Beverly Wildung Harrison (1983) makes a classic argument for a right to choose from within a religious tradition.

74 Dworkin (n 1) 137, 144. Dworkin (2011, p. 376) also revisits this issue in Justice for Hedgehogs, asking what 'fresh light' his argument about dignity could shed on the issue. He first argues that 'now, dignity provides the only available justification for freedom of religious thought and practice' (Dworkin 2011, p. 376). He then insists, 'once we accept that proposition, we can no longer consistently think . . . that religion is special and 
that when the Supreme Court decided 'a state lacks power to criminalize... early abortions', the Court 'had no choice' but to 'locate[]' its opinion doctrinally in 'the equal protection and due process clauses' rather than the 'First Amendment guarantees of religious freedom' because, while '[o]pponents of... abortion very often cite a god's will as warrant', few women 'who want choice in these matters conceive their desire as grounded in religion'75. (Again, I think a closer look at the religious landscape and studies of women's decisionmaking could have revealed that religious ethics do factor into some decisions to have an abortion.) Dworkin 76 refers back to his earlier attempt to argue for a substantive definition of religious convictions that would support a First Amendment approach to the abortion question: 'Religions attempt to answer the deeper existential question by connecting individual lives to a transcendent objective value'. In that earlier argument, he wrote: 'I can think of no plausible account of the content a belief must have, in order to be religious in character, that would rule out convictions about why and how human life has intrinsic objective importance'77. In Religion without God, he observes that the famous language from the Casey ${ }^{78}$ joint opinion - '[a]t the heart of liberty is the right to define one's own concept of existence, of meaning, of the universe, and of the mystery of human life'- is similar in substance to his previously offered definition of religion. Dworkin ${ }^{79}$ concludes, however, 'if, quite apart from the state of American constitutional law, we treat religious freedom as part of ethical independence, then the liberal position becomes man-

that other foundational ethical choices - about reproduction, marriage, and sexual orientation, for instance - may properly be subject to collective decision' (Dworkin 2011, p. 376).

75 Ibid 144-145.

76 Ibid 120-121.

77 Ibid 121.

78 Ibid 122.

79 Ibid 144-145. 
datory'. Dworkin 80 directs readers who are dismayed by 'this summary statement' to seek elaboration of his claims to Life's Dominion.

Given that Dworkin 81 only briefly treats the abortion issue in Religion without God, and that I have previously engaged with his arguments in Life's Dominion, I offer just a few comments about his claim that the liberal position becomes mandatory' if one frames the issue as one of ethical independence. First, some prominent figures on the other side of this particular culture war - for example, natural law theorist Robert P. George 82 - would strenuously resist any entitlement to ethical independence in this area, countering that taking seriously 'the moral argument for the sanctity of human life in all stages and conditions', reinforced by science, mandates respect and legal protection for even the earliest embryo. While the prolife movement, given that politics is 'the art of the possible', has 'settled on an incrementalist strategy for protecting nascent human life', saving 'many lives', George ${ }^{83}$ articulates:

Our foundational principle of the profound, inherent, and equal dignity of every human being demands that all members of the human family be respected and protected irrespective not only of race, sex, and ethnicity but also of age, size, location, stage of development, and condition of dependency. To exclude anyone from the law's protection is to treat him unjustly. ${ }^{84}$

In other words, what human dignity demands in the case of prenatal life is not a matter that can be left to a women's exercise of ethical independence; the only morally true answer is protecting life from destruction. George and Dworkin have starkly different views of how dignity is at stake in

80 Ibid 145 n. 19.

81 Ibid 144-145.

82 Ibid 93-95.

83 Ibid 95.

84 I emphasize these three terms since they seem particularly directed to describe the condition of embryos and fetuses. 
women's abortion decisions, since Dworkin views the abortion issue as one of ethics (whether a particular decision insults a woman's dignity by not taking seriously the sanctity of life) rather than morality (that is, a moral duty to the fetus). ${ }^{85}$ In this regard, Jeremy Waldron's ${ }^{86}$ critique of Life's Dominion's intervention into the 'culture wars' over abortion by clarifying what the argument is really about may be equally apt of Dworkin's effort, in Religion without God, to reorient the 'most divisive' abortion issue around the right to ethical independence: 'This was a valiant attempt to find common ground in a series of intractable debates, though I am not sure that it convinced anyone who held what we conventionally call a religious view of euthanasia or abortion'.

Second, it would be valuable to know how Dworkin would have assessed the emergence of the 'regret' rationale - that women often come to regret their decisions to have abortions - as a justification for regulating and restricting abortion. This argument rests on a view of what makes life a success and of what obligations women owe to others. As I discuss elsewhere, the idea is that women naturally would want to preserve their relationship with their unborn child and that, if they do have an abortion, either a physician did not inform them fully of the consequences of abortion or they were pressured by a family member or partner. Supporters of this argument offer narratives of women's lives that have gone

85 In Justice for Hedgehogs, Dworkin (2011, p. 377) clearly identified the regulation of abortion as one of ethics, not morality, indicating that the political community, via the Supreme Court, answered the moral question negatively, that is, whether a fetus has rights protecting its interest such that a woman has a 'moral duty not to abort'. Thus, Dworkin analyzes 'dignity' with respect to the woman's dignity, not that of prenatal life. He argues: 'That right [to ethical independence] is violated and denied when government restricts freedom in order to enforce a collective ethical judgment - in this instance the ethical judgment that a woman who aborts an early pregnancy does not show the respect for human life that her dignity demands' (Dworkin 2011, pp. 377-378).

86 Jeremy Waldron, "Review of Religion without god by Ronald Dworkin”, (2014) 94 BLR 1207.

\section{PROBLEMA}


badly after an abortion decision. On this view, in effect, women are incapable of choosing abortion, such that when they do choose it, society 'cannot trust that women really are exercising full moral capacity, and are responsible for their decisions'87. Thus, a 'friend of the court' brief filed in Gonzales v. Carhart [2007] 550 U.S. 124, in which the Supreme Court upheld a ban on a particular abortion method, contained many of these narratives and entirely rejected Casey's ([1992] 505 U.S. 833 at 851) premise that abortion is within the range of choices 'central to personal dignity and autonomy' and 'to the liberty protected by the Fourteenth Amendment'. The brief, filed on behalf of Sandra Cano, a plaintiff in a companion case to Roe v. Wade, instead contends that 'abortion hurts women and endangers their physical, emotional, and psychological health' (as cited in Fleming \& McClain 2013, p. 70)88. Acknowledging that there is "no reliable data to measure the phenomenon', Justice Kennedy, writing for the majority, cited the Cano brief in asserting that women come to regret their choice to abort the infant life they once created and sustained'. In upholding the ban on a method of abortion, he reasoned (Gonzales [2007] 550 U.S. 124 at 159) that women's regret might be worse and their sorrow 'more profound' if they later learned that their doctors did not fully inform them of the method of abortion used. This led Justice Ginsburg (Gonzales [2007] 550 U.S. 124 at 183) to chide him for invoking 'an anti-abortion shibboleth for which [the majority] concededly has no reliable evidence' and to remind the majority of Casey's language that 'the destiny of the woman must be shaped . . . on her own conception of her spiritual imperatives and her place in society'. To put Ginsburg's retort (Gonzales [2007] 550 U.S. 124 at 171-172, 182-183) in Dworkin's frame, the constitutional right Casey upheld protects ethical independence - a 'woman's autonomy to determine her life course'. As J. Fleming and I 89 argue, 'the

87 Fleming and McClain (n 52) 69.

88 Ibid 70.

89 Ibid 73. 
regret rationale reflects a lack of trust in women's capacity for responsible moral agency, and a view that women are incompetent decision makers who need protection from their decision'. In actuality, questions of ethical and moral responsibility feature centrally in pregnant women's decisionmaking; a 'friend of the court' brief filed in Carhart in opposition to the ban $^{90}$, which presented women's narratives, explained: 'These women rely upon intimate moral, religious, and personal values to make the right decision for themselves and their families' 91 . Thus, on the one hand, I wholly support Dworkin's argument that a woman's decision about pregnancy should be located within a frame of ethical independence. On the other hand, at this writing, it is hard to envision any philosophical intervention that could alter the current political and constitutional landscape concerning a right to procreative autonomy - where a woman's right to ethical independence is challenged in ever more restrictive ways on the rationales both (1) of protecting women's health, well-being, and 'right to know' (thus reducing the risk of 'regret'), and (2) of protecting fetal life. ${ }^{92}$

\section{Is Democracy Possible Here?: Identifying Shared Principles about the Value and Responsibilities of a Human Life}

In Is Democracy Possible Here?: Principles for a New Political Debate, published after the 2004 presidential election in the United States and amidst talk of polarization, Dworkin ${ }^{93}$

90 Institute for Reproductive Health Access et al. 2007, p. 29

91 Fleming and McClain (n 52) 74.

92 As I have written elsewhere (McClain 2006, pp. 248-252), a problem with appealing to 'responsibility' to defend abortion rights is that there is a gap between the reasons the public supports legal abortion and the reasons women most typically give for terminating their pregnancies. A woman's calculus of the 'responsible' or 'right' thing to do given her circumstances will not be persuasive to people who view abortion as generally chosen for reasons of 'convenience' or selfishness.

93 Dworkin (n 3) 1-2. 
tackled another contemporary form of 'war': American politics and the seemingly 'deep, schismatic rift in the nation as a whole' into 'incompatible all-embracing cultures', or 'red' versus 'blue' states. Dworkin'94 opened the book by observing the 'appalling state' of American politics. He proposed to bridge the 'supposedly unbridgeable divide' between red and blue states 'to find the common ground that makes genuine argument among people of mutual respect possible and healing'95. People, he argued, share two 'abstract, indeed philosophical, principles about the value and the central responsibilities of a human life' that involve dimensions of human dignity 96 . Dworkin ${ }^{97}$ articulated these two principles in terms of the 'objective' value of each human life: (1) once begun, it matters how [a human life] goes', and (2) the principle of personal responsibility 'each person has a special responsibility for realizing the success of his own life'. Those two dignity principles, he explained, form 'what a government is required to do': Dworkin 98 elaborated on the implications of the first principle, drawing on his familiar idea that government must treat people with 'equal concern'99 as a condition of political legitimacy. The second principle of human dignity, that 'political arrangements must respect people's personal responsibility for identifying value in their own lives', maps onto a 'partnership conception' of democracy, which recognizes limits to democratic self-government ${ }^{100}$. As Dworkin ${ }^{101}$ argues: 'It is inconsistent with someone's dignity ever to submit to the coercive authority of others in deciding what role religious or comparable ethical values should play in his

94 Ibid 5-7.

95 Ibid.

96 Ibid 6-7.

97 Ibid 9-10.

98 Ibid 94-97, 144-196.

99 For Dworkin's famous articulation (1977, pp. 272-78) of the right to equal concern and respect, see Taking Rights Seriously.

100 Ibid 145-147.

101 Ibid 145-146. 
life, so the partnership conception requires some guarantee that the majority will not impose its will in these matters'; constitutional rights are, thus, 'attempts to guarantee' that ethical freedom. ${ }^{102}$

Dworkin 103 submitted that once people understood that they shared these 'deep principles about human value', it will afford 'common ground' to make national political debate on terms of mutual respect 'possible and profitable'.104 Dworkin illustrated with examples of abortion, same-sex marriage, and religious liberty. I return to Dworkin's analysis of marriage in the next Section, because it will make more sense after I examine his earlier work condemning legal prohibition of homosexual conduct in terms of liberal equality, ethical independence, and equality of resources.

\section{RELIGION WITHOUT GOD AS A FORM OF ETHICAL LiBERALISM}

In this Section, I point out the continuity between Dworkin's prior work on ethical liberalism and his argument for key features in a 'religious attitude' in Religion without God. In particular, I observe his turn to liberal ethics, his appeal to art and the aesthetic as instructive on what it means to live life well, his emphasis on the role of personal responsibility in that ethics, and his insistence on value holism: the integration of ethics, morality, and justice (or, 'political morality', of which law is a branch ${ }^{105}$. Because

102 Dworkin (2011, pp. 385-99) further argues why these dignity principles support the partnership conception of democracy. For a sympathetic evaluation, see Imer Flores' Ronald Dworkin's Justice for Hedgehogs and Partnership Conception of Democracy (with a Comment to Jeremy Waldron's "A Majority in the Lifeboat") (2010, pp. 98-102).

103 Ronald Dworkin, Freedom's law: the moral reading of the American constitution, (HUP 1996) 6-8.

104 Elsewhere, I evaluate (McClain 2008, p. 435) Dworkin's strategy for finding common ground by looking at debates over family law, specifically, the definition of marriage.

105 Dworkin (n 10) 327-328, 400-409. 
Justice for Hedgehogs, Dworkin's epic argument'106 for 'the unity of value', has been the subject of extensive commentary ${ }^{107}$, I focus primarily on some of the earlier roots of ethical liberalism.

\section{Ethical Liberalism: Liberal Community and Foundations of Liberal Equality}

In his 1989 essay, Liberal Community, Dworkin ${ }^{108}$ already was considering what makes a life go well and what improves or hinders one's well-being. He wrote that essay as a critique of Bowers v. Hardwick [1986] 478 U.S. 186, in which the Supreme Court infamously upheld Georgia's criminal prohibition on sodomy —as applied to homosexual sodomy- because the majority of Georgia presumably deemed homosexuality to be immoral (at 196). Dworkin ${ }^{109}$ advanced a distinction between 'volitional' and 'critical' well-being; the former 'is improved whenever' someone 'achieves something he wants'. The latter, critical well-being, is 'improved only by his having or achieving those things that he should want, that is, achievements or experiences that it would make his life a worse one not to want'. 110 Correspondently, he recognized two forms of paternalism: 'volitional', which 'supposes that coercion can sometimes help people achieve what they already want to achieve, and is for that reason in their volitional interests'; and 'critical', which 'supposes that coercion can sometimes provide people with lives that are better than the lives they now think good and coercion is therefore sometimes in their

106 Ibid 1.

107 Kitchell and Segal (eds), "Justice for Hedgehogs: a conference on Ronald Dworkin's forthcoming book", (2010) 90 BULR

108 Ronald Dworkin, "Liberal community" (1989) 77 CLR 484-487, 502.

109 Ibid 484.

110 Ibid. 
critical interests'. ${ }^{111}$ As a tool for evaluating paternalism and whether it could improve lives, Dworkin ${ }^{112}$ argued for a 'constitutive view' of the 'critical value of a life': unless someone 'endorses' a component of his life, the value of his life is not improved. Accordingly, 'it is implausible to think that someone can lead a better life against the grain of his most profound ethical convictions'113. Thus, on this view, if a person who is homosexual does not lead a homosexual life out of fear of punishment, and thus 'never endorses the life he leads as superior to the life he would otherwise have led, then his life has not been improved' by the 'paternalistic constraints he hates'. ${ }^{114}$ Dworkin 115 further argued that '[t]hreats of criminal punishment corrupt rather than enhance critical judgment', so that even if those threats 'conver[ted]' someone away from homosexuality, such conversion 'cannot be counted as genuine in deciding whether the threats have improved someone's life'.

In his account of 'ethical liberal[ism]' or the 'challenge model', Foundations of Liberal Equality (delivered as the Tanner Lectures in 1989, and published in 1990), Dworkin ${ }^{116}$ reiterated his disagreement with Bowers, and its conclusion that 'a majority may properly make homosexuality a crime just because most people think homosexuals lead bad lives'. Returning to the example of political disagreement over whether homosexuals live good lives or not, he insisted that while people were free to 'campaign for the good', '[1]iberal equality denies them one weapon: even if they are in the majority, they must not forbid anyone to lead the life he wants, or punish him for doing so, just on the ground that they

111 Ibid 485.

112 Ibid 486.

113 Ibid.

114 Ibid.

115 Ibid 486-487.

116 Ronald Dworkin, "Foundations of liberal equality, lecture at The Tanner Lectures on Human Values”, (1990) 11 UUP, 112-114. 
think his ethical convictions are wrong'. ${ }^{117}$ (Here, Dworkin ${ }^{118}$ differentiates his strategy of 'continuity' between ethics and politics and what he takes to be John Rawls's strategy of discontinuity - that we should not bring our deepest convictions to bear in politics).

At that time, Dworkin ${ }^{119}$ explained this limitation in terms of the demand of equality of 'circumstances and resources', because '[t]he law is plainly part of people's circumstances, and circumstances are plainly unequal when the law forbids some to lead the lives they think best for them only because others disagree'. Again, Dworkin 120 insisted that 'ethical liberals' embraced tolerance, which 'gives full force to their abstract ethical convictions about how they and others can live best'. One of those convictions is that 'someone's life cannot be improved against his steady conviction that it has not been'121.

In Foundations of Liberal Equality, Dworkin ${ }^{122}$ also elaborated on the idea of 'living well' in developing a 'challenge' conception or model of ethics and liberal equality. ${ }^{123} \mathrm{He}$ illustrated this model by appealing to art and the aesthetic. Dworkin ${ }^{124}$ observes that the 'model of challenge' - by contrast to the 'impact model' - 'adopts Aristotle's view that a good life has the inherent value of a skillful performance', a value that holds whether or not that performance has any 'impact beyond the life in which [it] occur[s]'. Dworkin ${ }^{125}$

117 Ibid 114-115.

118 Ibid 20-22, 24.

119 Ibid 115.

120 Ibid 116.

121 Ibid.

122 Ibid 7-8.

123 Dworkin (n 116) 7-8. Distinguishing the 'challenge' from the 'impact' model and arguing that '[s]omeone lives well', on the challenge account of ethical value, "by having a decent sense of the assignment he faces in living - a decent sense of his own ethical identity-and leading that life out of that sense'.

124 Ibid 57.

125 Ibid 64. 
gives a number of examples of artistic creation, suggesting that art is a 'better analogy to living, according to the challenge model' than something like mountain climbing or diving. Pertinent to his later work on a religious attitude, he stresses that if living well is regarded as a challenge, defining what it is to live well must be part of that challenge too'126. For '[a]rtists are not furnished with blueprints', and '[t]here is no settled view about what artistic achievement is', as perhaps there is about achievement in diving ${ }^{127}$. Both art and ethics, Dworkin 128 contends, 'call for a decision, as part of the challenge they present, about the right response to the complex circumstances in which the decision must be made', and a further question, 'in both cases', is 'what the right response for any particular artist or person in any particular circumstances actually is, or whether there is a single right response even for a particular person or circumstance or only a set of these'.

Clearly, as I suggest in Part III, this idea of ethics differs from a model of religious ethics rooted in divine revelation and 'dictates' of conscience. Notably, Dworkin ${ }^{129}$ closes his Tanner Lectures with an Epilogue stating that he does not mean 'that religious or utilitarian ethics can have no place in the model of challenge'. Instead, he ${ }^{130}$ observes:

The idea that living skillfully means recognizing and entering into an appropriate relationship with some conception of God, or that it means recognizing and responding to human misery, are not only possible interpretations of the challenge model but, for many people, compelling interpretations of it. I mean only that many of the political implications people have drawn from theological or utilitarian ethics make sense only if these are understood on the different model of impact.

126 Ibid.

127 Ibid.

128 Ibid 66.

129 Ibid 119.

130 Ibid. 


\section{The Challenge Model and Value Holism: Justice for Hedgehogs}

In Justice for Hedgehogs, Dworkin ${ }^{131}$ argues for the integration of ethics, personal morality, and political morality, arguing that law is a branch of morality, broadly understood. There are many ideas in that rich book, and I previously have written about some of them. ${ }^{132}$ Here, I just observe that Dworkin carries forward in Justice for Hedgehogs his basic methods of appealing to readers' intuitions to explain principles they share and of drawing analogies to art and to performance to explain the importance -indeed, the challenge- of living well. To the central question, '[h]ow, then, should we live?', for example, Dworkin ${ }^{133}$ answers: 'We must treat the making of our lives as a challenge, one we can perform well or badly'. Dworkin ${ }^{134}$ refers to the Romantics' idea of making one's life a work of art in referring to 'the art of living', and to living life well as a skillful performance. Also carried forward is his argument 135 that a life lived well has 'adverbial' value, whether or not it has actual impact on others.

Principles of dignity - of self-respect and of authenticity - entail that each person has a 'special... responsibility for identifying what counts as success in his own life' and for creating a 'coherent narrative' of his life, a life he has chosen and endorsed ${ }^{136}$. This theme of endorsement dates

131 Dworkin (n 10) 405.

132 I have argued that Dworkin's book (McClain 2010, pp. 866-7) might be considered 'a work in "law and literature"' because of its focus on interpretation and on narrative, and I compared it with Muriel Barbery's (2006) best-selling novel, The Elegance of the Hedgehog.

133 Dworkin (n 10) 13.

134 Ibid 198-199.

135 Ibid 197.

136 Ibid 204. 
back to his 1989 article, Liberal Community ${ }^{137}$. Pertinent to Religion without God, he makes clear in his discussion of truth and objective value ${ }^{138}$ that he does not rely on a model resting on divine revelation or on the premise that a personal god is the ultimate source of morality. Utilizing distinctions he pursues in that later work, he distinguishes between the domains of fact ('if any god does exist') and value ('[a]ny god's moral authority, if this exists'), and that one must construct a principled account for such moral authority, rather than treating it as 'just a moral fact'139. Truth, like the other central concepts that Dworkin discusses in Justice for Hedgehogs — such as dignity, liberty, equality, and democracy - is an interpretive concept. ${ }^{140}$ Morally responsible people have the interpretive task of achieving integrity as they interpret - thus accepting their special responsibility for their own lives - what principles of authenticity and self-respect require in their lives ${ }^{141}$. Pertinent to Dworkin's later argument about the 'value' component of the religious attitude, he links ethics and morality ${ }^{142}$ through the concept of responsibility: '[W]hat people must do for their own sake or for others'. Translated into political morality, individuals have a right to ethical independence - to define ethical value for themselves, with corresponding limits on government's use of coercive power when it violates their ethical independence ${ }^{143}$ (as I elaborate in discussing the marriage example that follows).

137 Dworkin (n 108) 485-486. Argues for a 'constitutive' view of the critical value of a life on which 'no component contributes to the value of a life without endorsement'.

138 Dworkin (n 10) 173.

139 Ibid 343. For similar discussion in Religion without god, see Part III.

140 Ibid. Dworkin discusses interpretive concepts (pp. 156-170) and truth as such a concept (pp. 172-8) in Justice for Hedgehogs.

141 Ibid 99-117.

142 Ibid 327-328.

143 Ibid 368-369. 


\section{Personal Responsibility, Anticompulsion, and the Ethical} Environment: The Regulation of Same-Sex Marriage

Several years after Dworkin's critique of Bowers, first in the context of reproductive liberty in Casey and then in the overruling of Bowers in Lawrence v. Texas [2003] 539 U.S. 558, the U.S. Supreme Court affirmed the idea that governmental compulsion precludes the formation of belief in a manner that is consistent with respecting personhood. Dworkin favorably quotes the following passage from Casey [1992] 505 U.S. 833 in Life's Dominion and does so later in Religion without God: 'At the heart of liberty is the right to define one's own concept of existence, of meaning, of the universe, and of the mystery of human life. Beliefs about these matters could not define the attributes of personhood were they formed under compulsion of the State' (at 851).

In overruling Bowers and recognizing a constitutional right of gay men and lesbians to same-sex intimate association, Lawrence [2003] 539 U.S. 558 reiterated this anticompulsion principle, observing that constitutional '[1]iberty presumes an autonomy of self that includes freedom of thought, belief, expression, and certain intimate conduct' (at 562). Lawrence [2003] 539 U.S. 558 also repeated Casey's idea that people of good conscience disagree about the morality of homosexuality - as they do about what 'responsibility' means with respect to human reproduction and that the Supreme Court should not impose its own 'moral code', but 'uphold the liberty of all' (at 562). The Court's rhetoric in these two cases about liberty and autonomy and the beliefs that define 'the attributes of personhood' resonates, as Dworkin observes, with Dworkin's idea ${ }^{144}$ of ethical independence and of each individual's special responsibility 'to identify the value and point of human life and the relationships, achievements, and experiences that would realize that value in his own life'.

144 Dworkin (n 3) 71-72. 
In Liberal Community, Dworkin ${ }^{145}$ rejected the idea that a political community's 'communal life' should extend to a 'national' or 'communal sex life'. He contended that 'it is deeply implausible that the characterization of communal life that best fits' a community made up of '[p]eople of every race, faith, and ambition... could be one that assumes that it must choose one faith or set of personal ambitions or ethnic allegiance, or one set of standards of sexual responsibility, as a healthy individual person must'146. Thus, contrary to Bowers [1986] 478 U.S. 186, 'neither the United States nor its several states are communities that have a communal sex life, and... the argument from integration, used to justify illiberal political decisions by and across those political communities, accordingly fails'147. In this respect, the Supreme Court seemed to concur with Dworkin when, in Lawrence [2003] 539 U.S. 558, it affirmed a realm of autonomy in which consensual, intimate sexual conduct between adults may not be punished merely because a majority believes it is immoral. Liberty, the Lawrence Court stated, assumed an 'autonomy of self', and the Court observed that there was an 'emerging awareness' of such autonomy concerning intimate life (at 571-572). This runs counter to a presupposition of a nation with a communal sex life.

Is marriage different? Lawrence [2003] 539 U.S. 558 specifically did not address the issue of civil recognition of intimate relationships, although Justice O'Connor stated in concurrence that government has reasons, beyond mere moral disapproval, to protect the institution of marriage (at 585). As I elaborate elsewhere148, '[i]n the political order, families are simultaneously a site of private life and an institution of public importance because of the goods they foster and the functions they serve'. As the Massachusetts

145 Dworkin (n 108) 497-498.

146 Ibid.

147 Ibid 498.

148 Linda McClain, The place of families: fostering, capacity, equality, and responsibility, (HUP 2006) 22. 
Supreme Judicial Court well expressed it in Goodridge v. Department of Public Health [2003] 798 N.E.2d. 941, '[m]arriage is a vital social institution' with significant public and private dimensions (at 948). In contrast to government refraining from interfering with private individual sexual conduct — protected in Lawrence [2003] 539 U.S. 558 as part of due process liberty - government must take affirmative actions to create and recognize a civil marriage. Marriage entails liberty in the sense not only of 'freedom from' unwarranted governmental interference with intimate association but also of 'freedom to' marry the partner of one's choice and to governmental recognition of that union (Goodridge [2003] 798 N.E.2d 941 at 959).

How does a general right to ethical independence apply with respect to marriage? Are the laws regulating marriage tantamount to specifying a nation's 'communal sex life'? Do they violate Dworkin's insistence ${ }^{149}$ that the ethical environment 'be created under the aegis of ethical independence: that it be created organically by the decisions of millions of people with the freedom to make their own choices, not through political majorities imposing their decisions on everyone[?]' What is the proper mix between the realm of ethical independence - the environment created by numerous individual choices - and the realm of political morality -collective decision making in shaping marriage as a social and legal institution?.

Over a century ago, the Supreme Court famously, or infamously, declared, in Reynolds $v$. United States [1878] 98 U.S. 145 at 165-166 and subsequent cases upholding federal laws targeting polygamy that the United States rested on monogamous marriage, while polygamy undergirded despotism:

Marriage, while from its very nature a sacred obligation, is nevertheless, in most civilized nations, a civil contract, and usually regulated by law. Upon it society may be said to be built, and out of its fruits spring social relations and

149 Dworkin (n 10) 371. 
social obligations and duties, with which government is necessarily required to deal. In fact, according as monogamous or polygamous marriages are allowed, do we find the principles on which the government of the people, to a greater or less extent, rests. Professor Lieber says, polygamy leads to the patriarchal principle, and which, when applied to large communities, fetters the people in stationary despotism, while that principle cannot long exist in connection with monogamy.

In other words, 'the very government a society enjoys, whether despotic or republican, grows out of the form of marriage a society permits' 150 .

While Reynolds [1878] 98 U.S. 145 certainly has its critics, for its 'orientalism' and its trenching on the Establishment Clause ${ }^{151}$, it is notable that Goodridge [2003] 798 N.E.2d 941 at 954, over a century later, reiterated the role of law in setting the terms of the marriage contract:

In a real sense, there are three partners to every civil marriage: two willing spouses and an approving State. While only the parties can mutually assent to marriage the terms of the marriage - who may marry and what obligations, benefits, and liability attach to civil marriage- are set by the Commonwealth.

150 Mark Brandon. States of Union: family and change in the American constitutional order, (UPoK 2013) 206. Elsewhere, I review Brandon's informative book (McClain 2014).

151 Ibid 206. Observes critically 'several items of irony and interest' in Reynolds, including 'the Court's invocation of the sacred to limit religiously motivated action'. Brown v. Buhman [2013] 97 F. Supp. 2d 1170 struck down the 'cohabitation' prong of Utah's criminal bigamy statutes and questioning continued vitality of Reynolds given that the Supreme Court has over decades [since Reynolds] assumed a general posture that is less inclined to allow majoritarian coercion of unpopular or disliked minority groups, especially when blatant racism (as expressed through Orientalism/imperialism), religious prejudice, or some other constitutionally suspect motivation, can be discovered behind such legislation' (at 1181-1182). 
How, then, should a right to ethical independence feature in an account of governmental authority to define and regulate marriage? Is marriage an interpretive concept? Is there a 'truth' about what the best conception of marriage is, which the political community may support? Or is the liberal answer instead broad tolerance of diverse views about what marriage is and what it means? What happens when people disagree? ${ }^{152}$

Religion without God refers to Dworkin's prior analysis in Is Democracy Possible Here? in support of his argument 153 that a right to ethical independence makes 'mandatory' the 'liberal position' on 'gender equality in marriage'. I have analyzed that argument in other writing, and so I just briefly recapitulate it, suggesting the continuity with his overall account of ethical liberalism and asking how it bears on the project of 'Religion without God'. In Is Democracy Possible Here?, Dworkin frames the issue of access by gay men and lesbians to marriage as posing distributional and liberty questions. Recognizing that marriage is a social institution, he writes ${ }^{154}$ that marriage is 'a social resource of irreplaceable value', and submits that unequal access to it cannot be justified. Dworkin ${ }^{155}$ (characterizes certain arguments made against extending marriage to same-sex couples - such as promoting optimal child rearing - as reflecting a 'judgmental religious perspective' that is 'belied by the practice, in Massachusetts as well as other states, of permitting unmarried same-sex couples to adopt children'.

Dworkin ${ }^{156}$ concluded that the most sympathetic rendering of ' $[t]$ he case against gay marriage' was the following:

[T]he institution of marriage is... a unique and immensely valuable cultural resource. Its meaning and hence its value

152 I return to this in Part III.B, in examining Robert George's argument against changing civil law to allow same-sex couples to marry.

153 Dworkin (n 1) 145.

154 Dworkin (n 3) 86.

155 Ibid 87.

156 Ibid 87-88. 
have accreted organically over centuries, and the assumption that marriage is the union of a man and a woman is so embedded in its meaning that it would become a different institution, and hence a less valuable institution, were that assumption now challenged and lost. Just as we might struggle to maintain the meaning and value of any other great natural or artistic resource, so we should struggle to retain this uniquely valuable cultural resource.

Dworkin 157 then made an interesting move, suggesting that if one substitutes 'religion' for 'marriage' in the above argument, one would see that religion's meaning has changed over time, due to many 'organic processes' (such as the development of new religions) as well as due to 'new threats to established doctrine and practice' because of secular theories of science, politics, or social justice. So, too, religion's cultural meaning shifts as '[p]eople's sense of what religion is' alters as a result of social movements (such as feminism) and 'a thousand other shifts in religious impulse that began in individual decisions and ended in seismic changes in what religion can and does mean'158.

Dworkin 159 then moved from religion to marriage: religious conservatives, he contended, do not advocate freezing the cultural meaning of religion by laws prohibiting people with new visions from access to the title, legal status, or tax and economic benefits of religious organization'. But when they make a 'cultural argument against gay marriage', they assume - mistakenly - that 'the culture that shapes our values is the property only of some of us - those who happen to enjoy political power for the moment - to sculpt and protect in the shape we admire'160. In a 'genuinely free society', however, liberty and the personal responsibility it protects insist that the world of ideas and values belong to no

157 Ibid 88.

158 Ibid.

159 Ibid.

160 Ibid 89. 
one and to everyone'161. This argument is similar to Dworkin's argument against governmental coercion of the ethical environment.

As I now address, some prominent religious opponents of marriage equality do not believe that the definition -and hence the meaning - of marriage should be permitted to change, and contend that to permit such change would be a denial of the 'truth' of what marriage is. Is Dworkin's framing of the marriage issue as one of a right to ethical independence a persuasive way to meet that argument?

\section{Will Dworkin's 'Prayer' Be Answered?: CAN His Religion Without GOD REDUCE CONFLICT OVER RELIGIOUs LiBERTY?}

Dworkin'162 argues in Religion without God that 'a little philosophy might help' to 'shrink both the size and the importance' of the 'new religious wars' in the United States. Dworkin rejects the idea of a 'special right to religion', echoing his argument in Justice for Hedgehogs that the appeal to 'special rights and obligations', rooted in 'racial, ethnic, religious, and linguistic connections... has been and remains a powerful source of evil'163. Indeed, passages in that earlier book about people 'killing each other and destroying their communities in the name of some supposed group right or destiny'164 preview his concern in Religion without God: 'Religious war is, like cancer, a curse of our species. People kill each other, around the world, because they hate each other's gods. In less violent places like America they fight mainly in politics, at every level from national elections to local school board meetings'165.

As introduced in Part I, Dworkin's philosophical intervention into this 'war' is that 'logic requires a separation be-

161 Ibid.

162 Dworkin (n 1) 9-10.

163 Dworkin (n 10) 324.

164 Ibid.

165 Dworkin (n 1) 7-8. 
tween the scientific and value parts of orthodox godly religion', which allows us to see that theists and atheists share a religious attitude ${ }^{166}$. Turning to constitutional law, Dworkin ${ }^{167}$ then proposes to reorient the understanding of religious freedom to include 'religious atheism', or 'Religion without God', so that the core issue is 'ethical independence', which requires certain limits on governmental restriction of that freedom.

In this Part, I evaluate (1) whether Dworkin's conception of 'Religion without God' is likely to persuade theists, and (2) whether his proposed shift from a special right to religious freedom to a general right to ethical independence is likely to lead to 'religious liberty without conflict', or at least to less conflict. Or is this latest Dworkinian intervention another overly 'sunny assumption that reason [will] dissolve the deepest differences underlying our legal and especially our constitutional outlooks'168?

I first identify several lines of criticism that religious theists might direct toward Dworkin's argument. I also contrast Dworkin's argument, both on the religious attitude and on the liberal position on marriage becoming mandatory, with that of Robert P. George. This comparison is apt for three reasons. First, just as Dworkin offers interventions into culture wars, George ${ }^{169}$ contends that the deep divisions among Americans over a range of issues involve disputed fundamental values and moral principles' and proposes to look deeply and critically at underlying 'philosophical assumptions... about the human good, human nature, human dignity, and many other crucial matters'. Second, George's natural law approach ${ }^{170}$ separates reason and revelation, insisting that, while 'God can reveal moral truths,... many

166 Ibid 9.

167 Ibid 129-137.

168 Ibid 510.

169 Robert George, Conscience and its enemies: confronting the dogmas of liberal secularism, (Intercollegiate Studies Institute 2013) ix-x.

170 Ibid 83. 
moral truths, including some that are revealed, can also be grasped by ethical reflection apart from revelation'. Nonetheless, George's account of religion suggests that he would reject sharply much of Dworkin's account. Moreover, while Dworkin 171 contends that the 'liberal position' on abortion rights and same-sex marriage 'becomes mandatory' if one accepts his recasting of religious freedom, George ${ }^{172}$ argues that ' $[t]$ he defense of life against abortion' and '[t]he defense of marriage' are 'among the most urgent causes' that 'spring from the foundational moral purposes of law and the state'. Third, and related to this point, George, a prominent conservative Christian academic ${ }^{173}$, has taken a highly visible public role, not only through his published writing and friend of the court briefs (including with coauthors Ryan Anderson and Sherif Girgis), but also as a leader in various organizations, in opposing changing civil law to allow same-sex couples to marry on the basis that the 'truth' about marriage requires defending traditional marriage ${ }^{174}$. Further, he argues that marriage itself and religious liberty

171 Dworkin (n 1) 145.

172 George (n 169) 105

173 Kirkpatrick, "The conservative-Christian Big Thinker", New York Times (USA, 16 december 2009) 24.

174 George (n 169) 96-105, 126-146. George was a coauthor of the Manhattan Declaration, which puts forth a religiously grounded defense of traditional marriage (Kirkpatrick 2009, p. 24). He is also coauthor of another, related book (Girgis, Anderson \& George 2012), and coauthor with Anderson and Girgis of an amicus curiae brief (George et al. 2013) in the recent U.S. Supreme Court litigation over the Defense of Marriage Act and Proposition 8. He is also the past chairman of the National Organization for Marriage, which actively opposes efforts in the legislative and judicial arenas to revise marriage laws, and helped found and is a fellow of the Witherspoon Institute ('Marriage and the public good' 2008), which has issued various reports defending traditional marriage laws against revision. In addition, Robert George is the chair of the U.S. Commission on International Religious Freedom, an appointment viewed as highlighting 'the Catholic scholar's striking influence on Washington policy debates, spanning global human rights as well as marriage and pro-life advocacy' (Desmond 2013). 
are threatened by such changes ${ }^{175}$. In Religion without God, Dworkin 176 observes in his chapter on religious freedom, that 'what is undoubtedly the most divisive issue of all' is 'sexual and reproductive morality', by which he means abortion and 'gender equality in marriage' (or same-sex marriage).

\section{Criticisms of Dworkin's Philosophy of Religion}

One likely criticism that theists will make of Dworkin's philosophy of religion is that a relationship to a personal god is at the core of both the 'science' and 'value' components of religion and cannot be severed in the way Dworkin proposes. Having a relationship with the divine is one significant dimension of living well, or having a successful life. One reason, as Steven Smith ${ }^{177}$ argues, is that in religious interpretations of morality, 'the ultimate fulfillment' of such morality is thought to inhere in a loving relationship with God himself', who is a 'Friend with whom it is a supreme joy to be'. In this sense, Smith 178 argues, theistic morality is 'subjective' because of a belief in a personal God, a 'transcendent Person, whose essence is Love'.

Further, obedience to or living in conformity with the commandments of a personal god is precisely what, for many religious believers, living well or living a successful life means. What supplies the content of 'living well' if not religious teachings (teachings often attributed to divine

175 Robert George, "Marriage and Politics" National Review (USA 11 february 2013$) 34$. George (2013b, p. 34) has additionally written, 'If marriage is redefined, believing what virtually every human society once believed about marriage - that it is a male-female union - will be seen increasingly as a malicious prejudice, to be driven to the margins of culture. The consequences for observant Christians, Jews, Muslims, and others are becoming apparent'.

176 Dworkin (n 1) 144-145.

177 Steven Smith, "Is god irrelevant?" (2014) 94 BULR 1352-1353.

178 Ibid 1355. 
command or revelation)? Consider the many biblical verses that link obedience to God's commands to life 'going well' (for example, 'Honor your father and your mother, as the Lord your God commanded you, so that your days may be long and that it may go well with you in the land that the Lord your God is giving you' (Deuteronomy 5:16)). Consider, in the Jewish tradition, the word 'halakhah' (literally, 'to go' or 'to walk'), associated with the entire system of Jewish law as it applies to everyday life: 'In the Bible the good life is frequently spoken of as a way in which men are "to go", and the ultimate source of the law given to Moses on Sinai (My Jewish Learning 2014; The American-Israeli Cooperative 2014). Halakhah is "the "way" a Jew is directed to behave in every aspect of life, encompassing civil, criminal, and religious law' (My Jewish Learning 2014). Similarly, in Islam, the third Abrahamic religion, the term 'shari' a' refers to a 'total way of life', the 'path of correct conduct that God has revealed through his messengers, particularly the prophet Muhammad'179.

'[F]or Abrahamic religions', one reviewer has suggested, 'God is the creator and the ultimate source of morality and, therefore, religion is a source of both individual and collective value'180. For this reason, Dworkin's disaggregation of the religious attitude from a personal god may be a stumbling block for many to accepting his argument. For example, theological perspectives and religious ethics rooted in ideas about God as creator and about the moral significance of the created order, which reflects God's purposes

179 Richard Martin, Encyclopedia of Islam and the Muslim World, (2004) 618.

180 Rafael Domingo, "Religion for hedgehogs? An argument against the Dworkininan approach to religious freedom",(2012) 2 Oxford Journal of Law and Religion, 371-390. 
and design ${ }^{181}$, are likely to object strongly to the following claim Dworkin 182 makes:

Human life cannot have any kind of meaning or value just because a loving god exists. The universe cannot be intrinsically beautiful just because it was created to be beautiful. Any judgment about meaning in human life or wonder in nature relies ultimately not only on descriptive truth, no matter how exalted or mysterious, but finally on more fundamental value judgments. There is no direct bridge from any story about the creation of the firmament, or the heavens and earth, or the animals of the sea and the land, or the delights of heaven, or the fires of hell, or the parting of any sea or the raising of any dead, to the enduring value of friendship and family or the importance of charity or the sublimity of a sunset or the appropriateness of awe in the face of the universe or even a duty of reverence for a creator God.

Contrast this passage from Dworkin with the Genesis account of creation, where God 'saw everything that he had made, and indeed, it was very good' (Genesis 1:31), and the Genesis story in which God said, '[1]et us make mankind in our image, according to our likeness' (Genesis 1:26), and then blessed the males and females he created instructing them to '[b]e fruitful and multiply' and to 'fill the earth and subdue it' and 'have dominion' over every living thing (Genesis 1:27). ${ }^{183}$ For many religion scholars and believers, the idea of being made 'in the image of God' permeates their religious beliefs and approach to their place in the world. It is the foundation of human dignity. ${ }^{184}$

181 Smith (n 177) 1355. Argues that in the Jewish and Christian traditions, 'life and the universe are the creation of, and are governed by, a mindful and loving Person... [T] he whole is suffused with purpose and love'.

182 Dworkin (n 1) 24-25.

183 Below, I discuss the role Genesis plays in arguments for the conjugal model of marriage.

184 John Behr, The promise of the image TA Howard (ed) Imago Dei: human dignity in ecumenical perspective (The Catholic University of Amer- 
No doubt some contemporary theologians have modern and postmodern forms of theology that do not premise all of religious ethics upon creation. Nonetheless, the radical severance Dworkin proposes between the 'science' part of religion - belief in a 'personal god' or an idea of divine creation - and the 'value' component of the religious attitude may be rough going for many religious believers, who 'think that the universe, including the world of humanity, is the product of a loving and intelligent Author or Designer who created it according to a plan and for a good purpose'185. Indeed, one critique ${ }^{186}$ suggests that while Dworkin introduced his idea of Religion without God to include 'religious atheists', his 'understanding of religion renders irrelevant the theistic aspects of the great monotheistic religions', leading some to worry about 'what the terms of the peace treaty' in the new wars over religion will be. Stanley Fish 187 contends that Religion without God continues the liberal project of 'dismantling or bracketing the scaffolding of a religious edifice with God as its foundation and apex' and 'building from scratch a new edifice that will be furnished with meanings and values as powerful and justified as those [liberals] relinquished when they relinquished theism'. Fish ${ }^{188}$ concludes of this liberal project: 'Religion so reduced to a general (nondoctrinal, nonceremonial) conviction of the meaning of life without any account of its origin is perfectly acceptable to liberalism because it is liberalism'.

Religious critics may question whether an ethical responsibility to 'live well' or to make a success of one's life sufficiently maps onto religious understandings of what it means to live a good life. Is living well a broad enough um-

ica Press 2013) 16. States, 'Now what from a Christian perspective marks out the dignity of human beings is that, unlike the rest of creation (and even the angels), they alone are created in the image and likeness of God'.

185 Smith (n 177) 1355.

186 Robert Miller, "Dogmatic Philosophy" First Things (USA, 1 february 2014) vol. 240, 60-61.

187 Fish (n 19).

188 Ibid. 
brella concept that it can embrace 'living according to religious teachings' or, as it is sometimes put, to religious 'dictates'? The ethical individualism model seems to emphasize self-direction and the individual constructing a successful life. For Dworkin, aesthetic images of self-creation are a ready analogy for making a success of one's life. Thus, in the concluding pages of Religion without God, he harkens back to 'the Romantic poets' who 'said we should try to make our lives into works of art', suggesting that ; what they said can be applied to any life someone self-consciously leads supposing it to be a life lived well according to a plausible view of what that means'189. Here, Dworkin 190 references his earlier words in Justice for Hedgehogs about how someone 'creates a work of art from his life', analogizing the satisfaction one feels from doing 'something smaller well' -an achievement 'within life' - to thinking of one's overall life as 'an achievement complete in itself, with its own value in the art in living it displays'.

What some religious critics may find lacking in this account of living well as a work of art is any place for religious doctrine or religious community in shaping one's beliefs and practices about living a successful life. The zealous insistence on the right - and responsibility - of the individual to find value for himself may be at odds with a value holism by which an individual finds value in being part of a broader interpretive community. How does Dworkin's view of an individual, within an integrated approach to ethics and morality, compare to a theist's, or believer's view? The interpretive challenge in Dworkin's world is faced by the individual, who, to meet that challenge, even if a religious believer, should not live an unexamined life. In Justice for Hedgehogs, for example, Dworkin ${ }^{191}$ argues: 'You do not live as well as you might if you have never had occasion to reflect on what living well means for you in your situation'.

189 Dworkin (n 1) 157-158.

190 Ibid 158.

191 Dworkin (n 10) 420. 
He adds: 'For many people a good life is one observant in a particular religion. They may be right or wrong in the cosmology this assumes, but in either case their lives lack full dignity if they have never even pondered that cosmology'192.

Dworkin 193 also argues that, pursuant to dignity principles, the individual may be subject to influence, but '[w]e may not subordinate ourselves to the will of other human beings' in making decisions about the success of our lives. Does feeling bound by the claims of - or agreeing to the interpretive authority of - a normative community or text ever cross the line from influence to subordination?194 Or do sanctions employed by a religious community cross such a line? Contemporary battles over orthodoxy and heterodoxy illustrate that a component of some contemporary religions is an idea that some choices about how to live are off the table as forbidden by a religion. The controversies over sexual and reproductive morality, to which Dworkin refers, illustrate this. 195

In a criticism both of Justice for Hedgehogs and the manuscript of Religion without God, Rafael Domingo of University of Navarra ${ }^{196}$ argues that Dworkin's focus on the 'unity of value' is 'incomplete because it is not based on the

192 Ibid.

193 Dworkin (n 3) 10-17.

194 Dworkin (2011, p. 17) suggests that deferring to the judgments of a particular religious text or religious leader is a permissible form of influence rather than subordination when he writes, '[w]e must be careful to distinguish subordination so defined from a variety of ways in which others may influence us that do not involve subordination and that this principal of dignity therefore does not condemn'.

195 Whether particular denominations should allow same-sex couples to marry religiously is a contentious issue in some religious communities, with some churches excommunicating or defrocking clergy who perform such ceremonies, as well as religious groups calling for religious sanctions against pro-gay-marriage politicians (Kitts 2011; Levy 2013; Warikoo 2013). Hunter Stuart (2013) gives an example outside the United States. Another recent example is the prior Pope's criticism of American nuns for their vocal positions on certain social issues (Hawkins 2012).

196 Domingo (n 180) 389. 
"unity of the person", as religion is. The unity of the person, Domingo ${ }^{197}$ argues, integrates three dimensions: the individual, the social, and the transcendent. While ethical individualism stresses the special responsibility of each person for his or her life, the social (or 'we') dimension of religion includes the relationship to other persons, and the transcendent dimension pertains to a relationship with God198. Domingo's formulation 199 integrates what Dworkin would call the 'value' dimension with the 'science' dimension: '[T]he transcendent dimension develops when a person embraces the ultimate sense of his or her own life, aware of his or her creaturely condition and searching for the divine plan of the creator ('He')'. 200

On this idea of the social and transcendent dimensions of religion, consider this statement by Robert George ${ }^{201}$ about what religion and the good of religion is:

In its fullest and most robust sense, religion is the human person's being in right relation to the divine - the more than merely human source or sources, if there be such, of meaning and value. Of course, even the greatest among us fall short of perfection in various ways. But in the ideal of perfect religion, the person would understand as comprehensively and deeply as possible the body of truths about spiritual things and would fully order his or her life, and share in the life of a community of faith that is ordered, in line with those truths. In the perfect realization of religion, one would achieve the relationship that the divine - say God himself, assuming for a moment the truth of monotheism- wishes us to have with Him.

197 Ibid.

198 Ibid.

199 Ibid.

200 I should make clear that this is not my own view (particularly using the "He" pronoun to refer to the divine). I use this critique of Dworkin as illustrative of possible objections to his argument.

201 George (n 169) 118. 
To some extent, George and Dworkin might find common ground on the idea of a religious attitude entailing an innate and inescapable responsibility to try to make [one's] life a successful one' and a certain attitude about the universe as something of 'intrinsic value and wonder'202. When George 203 , however, writes about the 'distinct basic human good' of religion as a 'good that is uniquely architectonic in shaping one's pursuit of and participation in all the basic human goods' I wonder if ethical independence adequately captures what George intends. Is it too independent of a conception of religion that speaks of respect for human well-being in terms of respect for a person's 'flourishing as a seeker of religious truth... who lives in line with his or her best judgments of what is true in spiritual matters'204. Put differently, George ${ }^{205}$ speaks about religious liberty in a religious 'quest to understand religious truth and order one's life in line with it'. When Dworkin analogizes to artistic performance in explaining living well, it seems different from George's account of religion as representing 'our efforts to bring ourselves into a relationship of friendship with transcendent sources of meaning and value'206. (Remember Dworkin's insistence - discussed in Part II- that there is no 'blueprint' for such a performance).

Certainly, George would reject Dworkin's distinction between the parts of religion that are 'parasitic' on a personal god ('godly commitments' such as worship) and those that are more centrally concerned with 'value'207. Thus, George 208 asserts:

Our religious questioning, understanding, judging, and practicing shape what we do not only in the specifically 're-

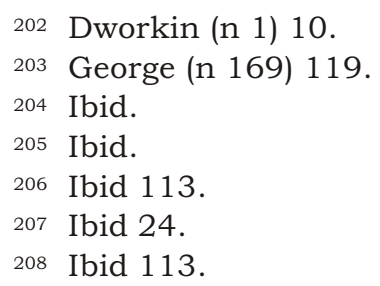


ligious' aspects of our lives (prayer, liturgy, fellowship, and so forth) but in every aspect of our lives. It helps us to view our lives as a whole and to direct our choices and activities in ways that have integrity - both in the moral sense of that term and in the broader sense of having a life that hangs together.

One might compare George's holistic picture of religion in human life to Dworkin's own argument for 'value holism'. Religion, George 209 argues, is a 'basic human good' that also fosters 'integrity' in the sense that it 'integrates all the other intrinsic and constitutive aspects of human well-being and fulfillment'. It is striking how George's natural law approach and Dworkin's ethical liberalism framework use so many similar terms, like integrity and intrinsic value, but reach such different conclusions about what religion is. Certainly, as I discuss below, they reach opposite conclusions about how these ideas apply to civil law and marriage.

George ${ }^{210}$ also stresses another function of religion that is not mentioned in Dworkin's book but that is central to discussions of the importance of religious liberty: religion, as an institution of civil society - an intermediate association between the individual and the state - plays a critical role in inculcating in persons the virtues crucial to America's 'experiment in ordered liberty'. 211 As I elaborate elsewhere, this is the civil society proposition: religious institutions, families, and other forms of association are 'seedbeds of virtue' that undergird and support the political order ${ }^{212}$. George (2013a, p. 22) also appeals to the role of such institutions as providing 'buffers' between 'the individual and

209 Ibid.

210 Ibid 20-22.

211 George (2013) states, '[W]e see the central political role and significance of the most basic institutions of civil society - the family, the religious community, private organizations (such as the Boy Scouts) devoted to the inculcation of knowledge and virtue, private (often religiously based) educational institutions, and the like' (pp. 20-2).

212 McClain (n 148) 50-54. Fleming and McClain (n 52) 81-111. 
the power of the central state', and warns of the threat to religious liberty when the state tries to usurp religion's functions. Jim Fleming and $\mathrm{I}^{213}$ have engaged this civil society proposition and offered an account of civil society's virtue generating and buffering functions in our elaboration of constitutional liberalism. Where we differ with George is not my point here; rather, what is striking about Dworkin's account of religion is that he does not address this institutional/civil society dimension of religion or indicate how a society produces persons capable of taking up the responsibilities of ethical liberalism so that they can make a success of their lives (Fleming \& McClain n.d.).

How might Dworkin respond to such criticisms? First, he qualifies his argument by explaining that he is not arguing 'against the science of the traditional Abrahamic religions' or 'that there is no personal god who made the heavens and loves its creatures'214. Rather, he reaches back to Hume and Plato to insist that a personal god 'cannot of his own will create right answers to moral questions or instill the universe with a glory it would not otherwise have'215. Dworkin puts the point provocatively. '[W]hether what displeases a god is morally wrong is not up to that god'; rather, a god's 'existence or character' can only figure as 'a minor premise' in the defense of some 'different, independent background value judgment'216. Dworkin ${ }^{217}$ returns to the fact/value distinction employed in his discussion of religion in Justice for Hedgehogs. Referring to 'the existence of a personal god' as a 'very exotic kind of scientific fact', Dworkin 218 appeals to 'Hume's principle', that one 'cannot support a value judgment —an ethical or moral or aesthetic claim- just by establishing some scientific fact about how

213 Ibid.

214 Dworkin (n 1) 25.

215 Ibid 25-26.

216 Ibid 26.

217 Dworkin (n 10) 137-138.

218 Dworkin (n 1) 26-27. 
the world is or was or will be. Something else is always necessary: a background value judgment that shows why the scientific fact is relevant and has that consequence'.

Domingo 219 counters that Dworkin's argumentation on this point is 'weak' and reflects a 'misconceived moral epistemology', again resisting Dworkin's distinction between the science and value parts of religion, and the fact/value distinction. ${ }^{220}$ Domingo 221 states, 'God is the supreme fact (Supreme Being in the Western tradition) and the supreme value (Supreme Good in the Western tradition), because, as creator, he gives the real meaning, the ultimate value, to human life and the universe'.222

Moreover, like George, Domingo 223 stresses that, in the natural law tradition, while revelation is one source of moral truth, reason is another, and the latter is open to all human beings. ${ }^{224}$ In this sense, there is some point of common ground with Dworkin. George 225 argues that 'natural law' - principles discernable through the exercise of practical reason - can 'provide some measure of common moral and even political ground for people who do not agree on the existence or the nature of God and the role of God in

219 Domingo (n 180) 375-376.

220 Ibid. States, 'In order to ensure the independence of morality from science and metaphysics, Dworkin must banish any idea of God from the field of value. However, this is a mistake...'

221 Ibid 377.

222 Smith (n 177) 23-25. Also discusses the 'great divide' between those who 'think that the universe, including the world of humanity, is the product of a loving and intelligent author or designer who created it according to a plan and for a good purpose, on the one hand, and on the other those who reject the belief in any guiding intelligence and any encompassing or mindful plan'.

223 Domingo (n 180) 377.

224 Ibid. Emphasizes that [ $\mathrm{r}$ ] eason is the meeting point between believers and non-believers. For believers, human reason is a gleam of the divine reason; for believers and non-believers, it is the most powerful human capacity to find the good'.

225 George (n 169) 83. 
human affairs'. At the same time, George ${ }^{226}$ says that he believes the answer is 'yes' to the question: 'Is there a divine source of the moral order whose tenets we discern in inquiry regarding natural law and natural rights?' George 227 insists:

[W]e should be open to the possibility that God has revealed himself in ways that reinforce and supplement what can be known by unaided reason. But we do not need agreement on the answer so long as we agree about the truths that give rise to the question - namely, that human beings, possessing the God-like (literally awesome) powers of reason and freedom, are bearers of a profound dignity that is protected by certain basic rights.

Is Dworkin's account of the religious attitude open in this way? Domingo ${ }^{228}$ and other critics conclude that it is not.229

In the chapter on 'Death and Immortality', Religion without God returns to the argument for the independence of the 'value' component of religion from a personal god (Dworkin 2013, pp. 149-159) ${ }^{230}$. Here, Dworkin ${ }^{231}$ evaluates ideas of immortal life and the premise that believers need 'the carrot of heaven and the stick of hell' and eternal punishment to motivate them to follow 'canons of living well' laid down by 'the Sistine God' in 'sacred texts' or revealed in prayer. Dworkin 232 first suggests that if 'living well' is 'an end in itself', then that personal god's 'main function is not to reward or punish but to instruct, guide, and judge'. Even so, on that account, Dworkin ${ }^{233}$ argues, 'those believers

226 Ibid.

227 Ibid 83-84.

228 Domingo (n 180) 381.

229 Ibid. States ' $\mathrm{M}$ ] oral epistemology should be open to the possibility of a transcendent reality, without any limitation besides reasonableness'.

230 Dworkin (n 1) 149-159.

231 Ibid 152.

232 Ibid 154.

233 Ibid. 
confront the apparent dilemma Plato described in the Euthyphro'. In the Euthyphro, Socrates repeatedly asked Euthyphro, 'What is "piety"?' and '[W]hether the just is always the pious', challenging Euthyphro's initial answer that '[p]iety, then, is that which is dear to the gods, and impiety is that which is not dear to them'234. Euthyphro later seems to agree with Socrates that the holy has been acknowledged by us to be loved of God because it is holy, not to be holy because it is loved'; but then reverts to defining piety or holiness as 'learning, how to please the gods in word and deed, by prayers and sacrifices', leaving Socrates in despair' and still asking Euthyphro to 'instruct [him] in the nature of piety and impiety'235. Dworkin ${ }^{236}$ explains the application of the Euthyphro dilemma to similar questions about the 'Sistine god':

Does the Sistine God create the right standard of living well just through this fiat? If so, then we cannot think we have really made our lives good just by obeying that fiat. We have only lived as our god wishes. That may be important to our safety, now and forever, but it is not to the moral or ethical point. Or is there an independent, objective standard of living well? In this case, the Sistine God has only his own opinion about what the standard holds. We might think we have good reason to think that that god's opinion is very likely to be better than our own. But what is indispensable is not that judgment about moral and ethical expertise but the necessarily prior judgment that there is an objective ethical and moral truth that someone might sensibly be thought to be an expert about. And that prior judgment does not depend on any theist assumption.

For Dworkin'237, it boils down to this crucial point: "What matters most fundamentally to the drive to live well is the conviction that there is, independently and objectively, a

234 Plato, "Euthyphro" in I Edman (ed) The works of Plato (1982) 35-50.

235 Ibid 53-55.

236 Dworkin (n 1) 154-155.

237 Ibid 155. 
right way to live'. This conviction is at the 'center of' a 'religious attitude to life' and '[i]n this most fundamental respect religious theists and religious atheists are as one'238. Where they may not be as one, however, is in how and where they find that 'right way to live'.

\section{Practical Problems: Marriage}

In his chapter on 'Religious Freedom', Dworkin239 proposes a 'radical reinterpretation' of religious freedom that would shift from conceiving a 'special right' for theists to a more general right to ethical independence. At the conclusion of this chapter he comes back to what he calls 'undoubtedly the most divisive issue of all: sexual and reproductive morality', referring to ongoing constitutional controversies over abortion rights and over whether same-sex couples have a right to marry ${ }^{240}$. Dworkin ${ }^{241}$ argues on both issues that if, quite apart from the state of American constitutional law, we treat religious freedom as part of ethical independence, then the liberal position becomes mandatory'. In this Section, I consider the potential of Dworkin's reframing to make progress on the marriage issue.

At this point, Dworkin242 incorporates by reference, rather than repeating, his prior arguments on these issues, for example, from Life's Dominion (on abortion) and Is Democracy Possible Here? (on 'gender equality in marriage'). As explained in Part I, Dworkin ${ }^{243}$ states that the Supreme Court had little choice but to ground its opinions limiting government power to criminalize 'early abortion' or 'homosexual acts' in the Due Process and Equal Protection

\footnotetext{
238 Ibid 155-156.

239 Ibid 133.

240 Ibid 144.

241 Ibid 144-145.

242 Ibid 144.

243 Ibid.
} 
Clauses of the U.S. Constitution rather than the First Amendment's guarantees of religious freedom, given that, while 'opponents of homosexuality and abortion very often cite a god's will as warrant', 'few men or women who want choice in these matters conceive their desire as grounded in religion'. His shift to ethical independence, with its broader view of religion, presumably would permit a new understanding, since men and women would view choice in these matters as a matter of exercising such independence. Will this approach persuade opponents of same-sex marriage or soften their opposition?.

Let's consider how people, exercising their ethical independence, make decisions about marriage individually and how a polity that accepts a right to ethical independence should regulate the institution of marriage. As previewed in Part II, we must consider the respective space for ethical independence and for political morality, that is, community settlement on the law of marriage. Dworkin states that the 'faith' that unites believers and nonbelievers is that they believe 'each person has an intrinsic and inescapable ethical responsibility to make a success of life'244. Each person, moreover, has a 'responsibility... to decide for himself ethical questions about which kinds of lives are appropriate and which would be degrading for him'245. Thus, 'a state violates that right whenever it prohibits or burdens homosexual practice, for instance'246.

Making individual ethical decisions is more complex when those decisions concern a social institution, such as marriage, which affords a legal framework for an intimate adult relationship. How does a political community assess whether or not to revise the definition of marriage to allow two men or two women to marry? Is Dworkin's insistence upon the exercise of ethical independence compatible with his insistence upon the objectivity of value? Is there a 'right'

244 Ibid 114.

245 Ibid.

246 Ibid. 
answer about what marriage is and who should be allowed to marry? If so, how is it discernible? Or is the liberal answer broad tolerance of diverse views about what marriage is and what it means? What happens when people disagree?

In the recent U.S. Supreme Court decision ${ }^{247}$, the majority held that section 3 of the Defense of Marriage Act (DOMA) (defining marriage, for purposes of federal law, as the union of one man and one woman) was unconstitutional. The majority opinion expressed what Dworkin might call the partnership conception of democracy that protects ethical independence in this way: the federal court has long deferred to states in the realm of domestic relations, but '[s]tate laws defining and regulating marriage, of course, must respect the constitutional rights of persons' (Windsor [2013] 133 S. Ct. 2675 at 2691). The Court cited as an example of such a limit on state power its prior opinion in Loving v. Virginia [1967] 388 U.S. 1, in which it struck down a state antimiscegenation law, which restricted a person's right to marry by barring them from marrying someone of a different race. This passage from the majority's opinion - and its citation to Loving - has featured prominently in the flurry of post-Windsor federal court decisions striking down state marriage laws banning same-sex couples from marrying or from having their marriages recognized under state laws. ${ }^{248}$ In language that Dworkin would likely have approved, the majority in Windsor [2013] 113 S. Ct. 2675 concluded that section 3 of DOMA was invalid 'for no legitimate purpose overcomes the purpose and effect to disparage and to injure those whom the State, by its mar-

\footnotetext{
247 United States $v$. Windsor [2013] 133 S. Ct. 2675

248 For example, the court in De Leon v. Perry [2014] 2014 WL 715741 [online] cited Loving when it stated, 'This fundamental right to marry also entails the ability to marry the partner of one's choosing' (at *34). The court in Bostic [2014] 970 F. Supp. 2d 456 noted, 'In signaling that due process and equal protection guarantees must trump objections to federal intervention, 'Windsor's "citation to Loving is a disclaimer of enormous proportion"' (at 476).
} 
riage laws, sought to protect in personhood and dignity' (at 2696), stressing the tangible and expressive value of marriage.

The dissenting opinions faulted the majority in Windsor [2013] 133 S. Ct. 2675 for taking sides in a profound cultural debate about two different views of marriage: a conjugal vision and a consent-based vision which emphasized 'mutual commitment' (at 2713-2719). Religious institutions and other groups (including George and his coauthors Ryan Anderson and Sherif Girgis) that advanced what Justice Alito called the 'conjugal model' warned about the harmful consequences to society if government departed from a time-honored understanding of what marriage is: " $\mathrm{A}] \mathrm{n}$ intrinsically opposite-sex institution', one 'inextricably linked to procreation and biological kinship' (Windsor [2013] 133 S. Ct. 2675 at 2718). Some rooted this conception of marriage in religious tradition; some appealed to a teleology of the body and of 'one flesh' union (Windsor [2013] 133 S. Ct. 2675 at 2718). All, I am confident, would say that they were defending the 'true' conception of marriage against a model that distorted marriage's meaning. Thus, in their coauthored and separate writings, George, Anderson, and Girgis argue that it is error for the secular government to depart from a correct understanding of what marriage is, thus building marriage law upon a distorted idea, 'falsehood', or a 'lie'. ${ }^{249}$ Moreover, they also warn that redefining marriage threatens religious liberty and traditional moral belief, as the belief that marriage is 'a union of a man and woman ordered to procreation and family life' is viewed as

249 George (n 175) Stated, 'The revisionist view would harm people (especially future generations) by distorting their idea of what marriage is'. Anderson (2013) added that, 'Marriage laws work by embodying and promoting a true vision of marriage, which makes sense of those norms as a coherent whole. . . . If the law taught a falsehood about marriage, it would make it harder for people to live out the norms of marriage because marital norms make no sense, as matters of principle, if marriage is just intense emotional feeling'. 
'malicious prejudice to be driven to the margins of culture'250.

Even though George 251 and his coauthors stress the consequences of redefining marriage for 'observant Christians, Jews, Muslims, and others', George ${ }^{252}$ contends that the view of marriage he and his coauthors advance reflects 'insights into the nature of marriage as a human good' and 'require no particular theology'; government should eschew being 'neutral' about marriage and instead, marriage law should reflect the 'sound understanding of marriage' as 'conjugal marriage'. In his writing with Anderson and Girgis, George (2012) similarly argues that they can support the one-man/one-woman definition of marriage even without appealing to Christian or Jewish teaching, but instead by appealing to an account of the purposes of marriage, rooted in the sexual complementarity of male and female and the procreative consequences of sexual union. They assert an objective truth of the matter and counter the rhetoric of 'marriage equality' by stating that, while 'we all want the law to treat all marriages equally', line drawing must reflect the 'truth' of what marriage is; same-sex unions, on their view, simply cannot realize the goods of marriage $^{253}$.

Some opponents of same-sex marriage appeal more directly to divine teaching and to the created order. Recall that, in calling for a separation of the 'science' part of religion from the 'value' part, Dworkin ${ }^{254}$ states:

There is no direct bridge from any story about the creation of the firmament, or the heavens and earth, or the animals of

250 Ibid.

251 Ibid.

252 George (n 169) 126-141.

253 Ryan Anderson "Marriage: what it is, why it matters, and the consequences of redefining it", 2014 Heritage Foundation, acessed 21 May 2014, http://www.heritage.org/research/reports/2013/03/marriage-wh at-it-is-why-it-matters-and-the-consequences-of-redefining-it.

254 Dworkin (n 1) 25. 
the sea and the land, or the delights of heaven, or the fires of hell, or the parting of any sea or the raising of any dead, to the enduring value of friendship and family...

This claim certainly runs counter to contemporary arguments about marriage and the family that appeal to a teleology of the created order, including the human body and sexual complementarity. On such views, the biblical accounts of creation, either that God created male and female in his own image, or more specifically, that he formed Eve out of Adam's rib and thus performed (as it were) the first marriage, support a view of marriage as the union of one man and one woman. This Genesis account is also a critical (even if not always explicit) foundation for Girgis, Anderson, and George's conjugal view of marriage as 'one flesh' union between one man and one woman. Girgis ${ }^{255}$, for example, argues that 'revelation' provides 'the outline' for what marriage is, citing to the Genesis creation stories, but that 'natural moral reasoning' helps to make sense of revelation with respect to the meaning of the 'one-flesh' union and the goods of marriage. ${ }^{256}$

For a not inconsiderable number of religious people, I argue, there are inferences drawn from the created world to the institution of marriage, such as the existence of two sexes - male and female - and even the divine command to 'be fruitful and multiply'. The mystery of one man and one woman joining in a 'one flesh' union undergirds a deep conviction about gender complementarity and the idea (as

255 Sherif Girgis 2014, "Reason and revelation: why Christians need philosophy", 2014 Public Discourse, http://www.thepublicdiscourse.com /2014/02/11978 accessed 21 may 2014.

256 Ibid. Also observes that marriage features as a 'mirror' for God's covenant with Israel and 'our union with Christ' when the Eucharist 'unites us bodily'. These more metaphorical uses of marriage are puzzling, given the author's emphasis on the 'one flesh' union of one man and one woman open to procreation.

\section{PROBLEMA}

Anuario de Filosofía y Teoría del Derecho,

Núm. 9, enero-diciembre de 2015, pp. 81-155 
George puts it) that mothers and fathers tend to bring different gifts to parenting'257.

How would replacing the idea of religious freedom with a more general right to ethical independence address such arguments about conjugal marriage and worries about religious liberty? No doubt Dworkin would have a ready answer to opponents of same-sex marriage who simply refer to divine authority and do not attempt, as do George and his colleagues, to provide a natural law foundation. For example, as New York State Senator Ruben Diaz, put it, in opposing New York's marriage equality law (invoking New York's archbishop): 'God, not Albany [the capital of New York], has settled the definition of marriage a long time ago' (New York State Senate 2011). Senator Diaz also referred to the 'great truth' that 'marriage is and should remain the union of husband and wife' and further argued that 'same-sex marriage is a government takeover of an institution that government did not create and should not define'258. And just recently, a former Texas state legislator now running for lieutenant governor quipped: 'I will change my definition of marriage when God changes his'259.

Dworkin would reply, I assume, that merely appealing to what a 'personal god' says —or does - is insufficient; there must be some independent source of value. Then the debate between the Dworkinian proponent of the liberal position on marriage and the proponent of conjugal marriage would be at the level of what the best interpretive concept of marriage was - as well as of marriage equality - or how the political community's definition must accord room to ethical independence.

257 George (n 175).

258 Diaz \& Long, 'If the NY Senate passes gay marriage, it's Republicans who will take the heat', 22 june 2011, National Review, http://www. national review.com/corner/270218/if-ny-senate-passes-gay-marriage-its-re publicans-who-will-take-heat-ruben-diaz accessed 22 May 2014.

259 Many Fernandez, 'Federal judge strikes down Texas' ban on same-sex marriage' New York Times (USA 27 February 2014) A13. 
One way that political liberals (and here I include myself) address this type of argument is to emphasize that there is a distinction between civil and religious marriage. Therefore, when same-sex couples seek to marry civilly, they are not challenging religious definitions of marriage that are part of someone's comprehensive moral view; religious institutions remain free to marry or not marry couples according to their beliefs. Recall Goodridge [2003] 798 N.E.2d 941 stressing that civil marriage, in Massachusetts, is a secular institution (at 954). Is this sharp line drawing between civil and religious marriage available to a Dworkinian approach to the marriage controversy? How might Dworkin respond to arguments, like those of George, Anderson, and Girgis, that eschew (for the most part) any overt reference to God but contain a teleology of marriage rooted in ideas of the body and of marriage's purposes? As an interpretive matter, I do not believe that their argument about the truth about marriage is reasonable or a sound basis for law and policy. It does not map well with contemporary family law about civil marriage or constitutional law concerning intimate association, marriage and family. After all, in the landmark case Griswold v. Connecticut [1965] 381 U.S. 479, the Court declared marriage a 'noble' association, 'intimate to the degree of being sacred', in a case striking down a state ban on the use of contraception by married couples (at 486). (In fact, they are quite critical of certain features of contemporary family law, such as no-fault divorce laws, viewing such changes as weakening marriage by a 'revisionist view that is more about adults' desires than children's needs' 260 It is a comprehensive moral view (to use Rawls's concept here) that is not publicly accessible by people who do not share their distinctive teleological analysis of conjugal union and should not be the basis for civil marriage law. ${ }^{261}$ They do not have a persuasive answer to why, on

260 Anderson (n 253).

261 In a book in progress, A Future for Marriage?, Stephen Macedo (2014) offers a thorough and persuasive critique of their argument, from a 
their view of the goods of marriage, state laws that permit marriage by opposite sex couples who are infertile, elderly, or do not intend to procreate, or who will be able to procreate only through means of reproduction that do not involve their 'one flesh' bodily union, should not also allow same-sex couples to marry, particularly when some of those couples may intend to become parents through adoption or assisted reproduction ${ }^{262}$. Moreover, the insistence that gender complementarity is essential to marriage and to parenting runs contrary to contemporary family law, which reflects the transformation from the common law model of marriage with its fixed, hierarchical roles of husband and wife and even from the complementary roles of separate spheres ideology to the present day conception of marriage as an equal partnership. So, too, the law of parentage and the law of custody largely reject preferences in favor of mother or based on premises about gender differences in parenting. ${ }^{263}$ Courts have repeatedly rejected appeals to procreation and to optimal child rearing as rationales for excluding same-sex couples from marriage, pointing out that procreation is not a prerequisite to marriage and that same-sex and opposite-sex couples are similarly situated in

political liberal perspective. Macedo (2014) analyzes the George, Anderson, and Girgis conception of marriage as an example of the "New Natural Law" and concludes, with respect to that conception:

The law of a religiously diverse political community ought not to be based - indeed, it may not legitimately be based - on philosophically or religiously sectarian systems of thought such as that supplied by the New Natural Law. The New Natural Law's conception of marriage and sex is perfectly respectable if conceived as the perfectionist ethic of those who embrace its system of ideas and commitments. If asserted as a guide to the law that will be imposed on all, then it fails to respect the range of reasonable views concerning marriage and sexuality in our society.

262 George (n 169) 133-134.

263 For critical evaluation of appeals to gender complementarity in light of these changes in family law, see the work of Susan Frelich Appleton (2013, pp. 237-245) or Linda C. McClain (2006a, pp. 327-343). 
their capacity to be loving, responsible parents. 264 Here, courts are also considering and rejecting moral arguments: that, somehow, having gay or lesbian parents is harmful to child outcomes. Instead, inspired by Justice Kennedy's reference in Windsor [2013] 133 S. Ct. 2675 to the humiliation that children of lawfully married same-sex couples face when the federal government does not recognize their marriage, courts striking down state marriage laws stress the harm to children from not allowing their parents to marry or have their marriages recognized (at 2695).

Effective rebuttals of arguments against revising civil marriage laws to permit same-sex marriage may well be available under Dworkin's framework, but I believe the distinction (supported by political liberalism as well as by the religion clauses of the Constitution) between civil and religious marriage makes it easier to make such rebuttals, because one need not prove who has the better view of what marriage 'really' is, depending upon one's ethical convictions about the universe and about value. That said, a recent federal district court opinion striking down Virginia's statutory and constitutional ban on marriage by two persons of the same-sex does provide a fruitful example of a Dworkinian idea of battles over an interpretive concept (Bostic v. Rainey [2014] 970 F. Supp. 2d 456). Judge Arenda Wright Allen observed that all the parties before her 'appreciate the sacred principles embodied in our funda-

264 An early example is Goodridge [2003] 798 N.E.2d 941 at 954. A recent example is DeBoer $v$. Snyder [2014] 973 F. Supp. 2d 757, in which there was a bench trial on the challenge brought by same-sex couples to Michigan's constitutional amendment barring marriage by same-sex couples or recognition of such marriages. The State of Michigan argued that one justification for Michigan's marriage amendment was the premise that heterosexual married couples provide the optimal environment for raising children' DeBoer [2014] 973 F. Supp. 2d 757 at 770 . The court rejected that rationale, finding that 'state defendants cited a small number of outlier studies in support of the optimal child-rearing rationale', but that 'the overwhelming weight of the scientific evidence supports the "no differences" viewpoint' DeBoer [2014] 973 F. Supp. 2d 757 at 770-771. 
mental right to marry'; that is, each 'cherishes the commitment demonstrated in the celebration of marriage' and 'embraces the Supreme Court's characterization of marriage as "the most important relation in life" and "the foundation of the family and society, without which there could be neither civilization nor progress"' (Bostic [2014] 970 F. Supp. $2 \mathrm{~d} 456$ at 471). 'Regrettably', she continued, 'the Proponents and the Opponents of Virginia's Marriage Laws part ways despite this shared reverence for marriage... over a dispute regarding who among Virginia's citizenry may exercise the fundamental right to marry' (Bostic [2014] $970 \mathrm{~F}$. Supp. 2d 456 at 472). The court resolved that dispute by appealing to constitutional principles, that is, principles of due process liberty and equal protection and Windsor's teaching that the state's authority to regulate marriage is subject to the federal constitution, by analogy to Loving. Judge Allen rejected the idea that plaintiffs sought to exercise a 'new' right, countering that they simply sought to enjoy the 'same' right enjoyed by 'heterosexual individuals: the right to make a public commitment to form an exclusive relationship and create a family with a partner with whom the person shares an intimate and sustaining emotional bond' (Bostic [2014] 970 F. Supp. 2d 456 at 472). Such a right, she continued, quoting another federal district ruling striking down Utah's marriage ban, 'is deeply rooted in the nation's history and implicit in the concept of ordered liberty because it protects an individual's ability to make deeply personal choices about love and family free from government interference' (Bostic [2014] 970 F. Supp. 2d 456 at 472). To frame this in Dworkin's approach, this interpretation of the right to marry protects an individual's right to ethical independence in the foundational matter of intimate life. Recall Dworkin's insistence, in all of his work, that, pursuant to principles of dignity, coercive government is legitimate only when it attempts to show equal concern for the fates of all it governs and full respect for their personal 
responsibility for their own lives 265 . Dworkin might observe that a state's failure to recognize a valid out of state marriage entered into by its citizens or its ban on marriage by same-sex couples failed to show equal concern for fate of all it governs or to respect their dignity. Here, the liberal use by the federal district courts in Virginia, Utah, Oklahoma, and elsewhere of Justice Kennedy's language in Windsor fortifies this point: in addition to not showing respect for their ethical independence by respecting their choice of marriage partner, these restrictions 'demean' their existence, humiliate their children, and so forth. ${ }^{266}$

The brevity of Religion without God leaves a reader wanting to know how Dworkin might address the explosion of evident conflicts, as more states change their civil marriage laws, between religious liberty and marriage equality. This is the conflict, as discussed previously, of which George and his colleagues frequently write. Invoking the rhetoric of the dissenting opinions in Windsor, they warn that, '[b]y deeming conjugal marriage supporters bigots, the [Supreme] Court makes it easier for lawmakers and courts to use anti-discrimination laws and public education to drive us to the margins of public life'267 Reframed as a right to ethical independence, rather than a special right, what sort

265 Dworkin (n 3) 145-147. Stated, 'It is inconsistent with someone's dignity ever to submit to the coercive authority of others in deciding what role religious or comparable ethical values should play in his life, so the partnership conception requires some guarantee that the majority will not impose its will in those matters...

266 For example, De Leon [2014] 2014 WL 715741 [online] states, 'Texas's current marriage laws deny homosexual couples the right to marry, and in doing so, demean their dignity for no legitimate reason'.

267 Girgis (n 255). In Windsor [2013] 133 S. Ct. 2675, Justice Alito contends that to apply heightened scrutiny to DOMA would 'cast all those who cling to traditional beliefs about the nature of marriage in the role of bigots or superstitious fools' (at 2717-2718), and Chief Justice Roberts states, '[W]ithout some more convincing evidence that [DOMA's] principal motive was to codify malice, and that it furthered no legitimate governmental interests, I would not tar the political branches with the brush of bigotry' (at 2696). 
of right does a religious person have to, for example, refuse goods and services to a same-sex couple because to do so, he or she argues, compromises the ability to define ethical values and live by those values? ${ }^{268}$ If a religious person is a public official, may he or she be free to refuse to issue a marriage license due to religious conviction? Dworkin ${ }^{269}$ offers only a brief hint of his approach, when he considers how the requirement of 'equal concern' might bear on the question of exemptions from the obligation to obey general, nondiscriminatory laws. Government, he says, must 'notice whether any group regards the activity it proposes to prohibit or burden as a sacred duty', and if so, 'must consider whether equal concern for that group requires an exemption or other amelioration', if giving one can be done 'with no significant damage to the policy in play'270. Contrary to what actually happened in Massachusetts, thus, Dworkin writes that 'financing Catholic adoption agencies that do not accept same-sex couples as candidates, on the same terms as financing agencies that do, might be justified in that way, provided that enough of the latter are available so that neither babies nor same-sex couples seeking a baby are injured'271. But he also argues for the "priority of nondiscriminatory collective government over private religious exercise' as 'inevitable and right', for example, refusing an exemption when giving one 'would put people at a serious risk that it is the purpose of the law to avoid'272. I regret that we cannot look forward to Dworkin's further contribu-

268 A prominent case invoked in these discussions is Elane Photography $v$. Willock [2013] 284 P.3d 428, which upholds the lower court's ruling that applying New Mexico's public accommodation law to a photographer who refused, because of Christian beliefs, to photograph a same-sex commitment ceremony did not violate the Free Exercise Clause of the First Amendment (at 445). The Supreme Court declined to hear the case (Elane Photography [2013] 284 P.3d 428 at 445).

269 Dworkin (n 1) 136.

270 Ibid.

271 Ibid.

272 Ibid 136-137. 
tion on the religious exemption and religious accommodations issues, which are likely to be of increasing concern as new political majorities expand protection of persons from discrimination based on sexual orientation, including in civil marriage laws.

\section{CONCLUSION}

I conclude this Article on a more personal note. At a symposium held at Boston University School of Law several years ago, Dworkin, in offering a response to the many commentaries on his manuscript for Justice for Hedgehogs, remarked that the event - gathering numerous people to 'come together to discuss a book of mine' before publication so he could 'benefit from what they say' - was his vision of heaven. He continued: 'The best part is that I don't even have to die'. In the final chapter of Religion without God, Dworkin begins by reporting Woody Allen's quip, when he 'was told that he would live on in his work', that 'he would rather live on in his apartment'273. It has been a palpable if bittersweet pleasure to read Dworkin's final book, Religion without God, mindful that he had 'planned to greatly extend his treatment of the subject over the next few years', but was prevented from doing so by illness ${ }^{274}$. The book is based on lectures, which are so vividly and characteristically in Dworkin's voice that it is really like being in a room hearing him speak again. As Moshe Halbertal observes $^{275}$, a unique feature of Religion without God is that Dworkin 'conveys a philosophical, even spiritual sensibility', with the ambition of bringing about 'a transformation in the way we see the world and in the stance we take toward the most basic features of our existence'. As I read Religion without God, I thought bac $\mathrm{k}$ to the Epilogue of Justice

273 Ibid 149.

274 Ibid ix

275 Ibid 1 
for Hedgehogs, in which Dworkin 276 made this observation about the importance of meeting the challenge of living well in one's situation:

Remember, too, that the stakes are more than mortal. Without dignity our lives are only blinks of duration. But if we manage to lead a good life well, we create something more. We write a subscript to our morality. We make our lives tiny diamonds in the cosmic sands.

This passage from Dworkin reminds me of one of my favorite poems, A Psalm of Life, by Henry Wadsworth Longfellow. In it (Longefellow 1906, pp. 49-50)277, the poet exhorts us that 'Life is real! Life is earnest', and declares:

Lives of great men all remind us We can make our lives sublime, And, departing, leave behind us Footprints on the sands of time; Footprints, that perhaps another, Sailing o'er life's solemn main, A forlorn and shipwrecked brother, Seeing, shall take heart again. Let us, then, be up and doing, With a heart for any fate; Still achieving, still pursuing, Learn to labor and to wait. ${ }^{278}$

\section{BIBLIOGRAPHY}

Anderson Ryan 2013, Marriage: what it is, why it matters, and the consequences of redefining it, Heritage Foundation, viewed 21 May 2014, http://www.heritage.org/research/reports/2013/03/marriage-what-it-is -why-it-matters-and-the-consequences-of-redefining-it.

276 Dworkin (n 10) 423.

277 Henry Longefellow Henry Wadsworth Longefellow (Houghton, Mifflin and Co. 1906).

278 Dworkin, of course, might well view this poem as expressing an impact, rather than adverbial model of life going well! 
2014, Marriage matters, and redefining it has social costs, Public Discourse, viewed 21 May 2014, http://www.thepublicdiscourse.com/2014/01/11880.

Appleton SF, 'Gender and parentage: family law's equality project in our empirical age', in LC McClain \& D Cere (eds.), What is parenthood? Contemporary debates about the family, (New York University Press 2013).

Barbery M, The elegance of the hedgehog, trans. A Anderson, (Eurpopa Editions 2008).

Behr John, 'The promise of the image', in TA Howard (ed.), Imago Dei: human dignity in ecumenical perspective, (The Catholic University of America Press 2013).

Brandon Mark, States of union: family and change in the American constitutional order, (University Press of Kansas 2013).

Catholics for Choice 2014, About us, Catholics for choice, viewed 13 March 2014, http://www.catholicsforchoice.org/about.

Diaz R \& Long M 2011, 'If the NY Senate passes gay marriage, it's Republicans who will take the heat', National Review, 22 June, viewed 22 May 2014, http://www. nationalreview.com/corner/270218/if-ny-senate-passes-gay-marriage-its-republicans-who-will-take-heat-r uben-diaz.

Desmond JF 2013, 'Robert George to head U.S. commission on international religious freedom', National Catholic Register, 25 July, viewed 21 May 2014, http:// www. ncregister.com/site/print_article/38319.

Domingo Rafael, 'Religion for hedgehogs? An argument against the Dworkinian approach to religious freedom', (Oxford Journal of Law \& Religion 2012) vol. 2, pp. 371-390. 
Dworkin Ronald, Taking rights seriously, (Harvard University Press 1977).

— Law's empire, (Belknap Press 1986).

, 'Foundations of liberal equality, lecture at The Tanner Lectures on Human Values', in GB Peterson (ed.), The Tanner Lectures on Human Values, vol. 11, (University of Utah Press 1990).

, 'Liberal Community', (California Law Review 1989).

, 'Unenumerated Rights: Whether and how Roe should be Overruled', (University of Chicago Law Review 1992).

, Life's Dominion: An Argument about Abortion, Euthanasia, and individual freedom, (Knopf 1993).

— Freedom's law: the moral reading of the American constitution, (Harvard University Press 1996).

- Is Democracy Possible Here?: Principles for a New Political Debate, (Princton University Press 2006).

- Justice for hedgehogs, (Belknap Press 2011).

—, Religion without God, (Harvard University Press 2013).

Fernandez M, 2014, 'Federal judge strikes down Texas' ban on same-sex marriage', New York Times, 27 February, p. A13.

Fish S 2013, 'Deeper than God: Ronald Dworkin's religious atheism', New York Times, 23 September, viewed 21 May 2014, http://opinionator.blogs.nytimes.com/ 2013/09/23/deeper-than-god-ronald-dworkins-religi ous-atheism.

Fleming James \& McClain Linda , Ordered liberty: rights, responsibilities, and virtues, (Harvard University Press 2013).

'Dworkin's perfectionism', in L Malik (ed.), Law and dignity: essays in honour and memory of Professor 
Ronald Dworkin, Oxford University Press, New York City, NY.

Flores Imer, 2010 'Ronald Dworkin's justice for hedgehogs and partnership conception of decomcracy (with a comment to Jeremy Waldron's "A Majority in the Lifeboat")', Problema: Anuario de Fliosofia y Teoria del Derecho, vol. 4, pp. 65-102.

George Robert, Conscience and its enemies: confronting the dogmas of liberal secularism, (Intercollegiate Studies Institute 2013a).

, 'Marriage and Politics', (National Review 2013b), 11 February, p. 34.

Girgis S, 2014a, Reason and revelation: why Christians need philosophy, Public Discourse, viewed 21 May 2014, http://www.thepublicdiscourse.com/2014/02 / 11978.

— $2014 \mathrm{~b}$, Why fight for marriage?, Public Discourse, viewed 21 May 2014, http:/ / www.thepub licdiscourse.com/2014/02/11982.

, Andersen, RT \& George, RP 2012, What is marriage? Man and woman: a defense, Encounter Books, Jackson, TN.

Halbertal M 2013, 'Can you have Religion without God? Ronald Dworkin and a religious worldview for secularists', New Republic, 26 October, viewed 21 May 2014, http://www.newrepublic.com/article/114898/ ronald-dworkins-religion-without-god-reviewed-religio s-worldview.

Harrison BW, Our right to choose: toward a new ethic of abortion, (Beacon Press 1983).

Hawkins B 2012, 'Sister Brigid McDonald calls Vatican's reprimand of U.S. nun group a "misuse of power"', MinnPost, 4 May, viewed 21 May 2014, http://www. minnpost.com/minnpost-asks/2012/05/sister-brigid- 
mcdonald-calls-vaticans-reprimand-us-nuns-group-mi suse-power.

Kirkpatrick DD, 'The Conservative-Christian Big Thinker', (New York Times 2009), 16 December, p. 24.

Kitts A 2011, 'Synod PJC upholds Sphar's conviction on same-sex wedding charge', Presbyterian Church, 31 March, viewed 21 May 2014, https://www.pcusa. org/news/2011/3/31/synod-pjc-upholds-spahrs-con viction-same-sex-weddi.

Levy G 2013, 'Church defrocks minister for officiating son's gay wedding', United Press International, 19 December, viewed 21 May 2014, http://www.upi.com/blog/ 2013/12/19/Church-defrocks-minister-for-officiatingsons-gay-wedding/5361387467941.

Longefellow HW, 'Henry Wadsworth Longefellow', Houghton, (Mifflin and Co. 1906).

Macedo Stephen, 2014, A future for marriage, in possession of the author.

Martin Richard, 2004, Encyclopedia of Islam and the Muslim world, London.

McClain Linda, "Toleration, autonomy, and governmental promotion of good lives: beyond "empty" toleration to toleration as respect', (Ohio State Law Journal 1998) vol. 59, pp. 91-100.

, "God's Created Order", Gender Complemantarity, and the federal marriage amendment', (Brigham Young University Journal of Public Law 2006a) vol. 20, pp. 313-343.

, The place of families: fostering capacity, equality, and responsibility, (Harvard University Press 2006b).

'Red versus blue (and purple) states and the same-sex marriage debate: from values polarization to common ground?', (University of Missouri Kansas City Law Review 2008) vol. 77, pp. 415-435. 
, 'Justice and elegance for hedgehogs - in life, law, and literature', (Boston University Law Review 2010) vol. 90, pp. 866-7.

, 'Common and uncommon families and the American constitutional order', (Vanderbilt Law Review En Banc2014) vol. 67, p. 19.

Miller Robert, 2014, 'Dogmatic Philosophy', First Things, vol. 240, pp. 59-61.

Movseian M 2013, 'Religion without god', First Things blog, web log post, 31 October, viewed 24 March 2014, http://www.firstthings.com/blogs/firstthoughts/201 3/10/religion-without-god.

Murn 2013, 'Book review: Religion without god', Humanist, 20 December, viewed 21 May 2014, http://thehumanist.org/january-february-2014/religion-without-god.

My Jewish Learning, Halakhah: Jewish Law, My Jewish Learning, viewed 14 May 2014, http://www.myje wishlearning.com/practices/Ritual/Jewish_Practices /Halakhah_Jewish_Law_.shtml.

National Organization for Marriage 2014, Leadership, National Organization for Marriage, viewed 2 April 2014, https:// nationformarriage.org/about /leadership.

Perry MJ , Toward a theory of human rights: religion, law, courts, (Cambridge University Press 2007).

Plato, 1982, Euthyphro, in I Edman (ed.), The works of Plato, pp. 35-50.

Smith, SD, 'Is God irrelevant?', (Boston University Law Review 2014), vol. 94, p. 1339.

Staurt H, 2013 'Pope Francis excommunicates Australian priest who advocated for gay marriage and female clergy', Huffington Post, 24 September, viewed 21 May 2014, http://www.huffingtonpost.com/2013/09 124/pope-francis-excommunicates-priest-greg-reynol ds_n_3983059.html. 
Kitchell SJ \& Segal JMD (eds.), 'Justice for hedgehogs: A conference on Ronald Dworkin's forthcoming book', (Boston University Law Review 2010), vol. 90, p. 465 (2010).

The American-Israeli Cooperative Enterprise, Halakhah: definition, Jewish Virtual Library, viewed 2 April 2014, http://www.jewishvirtuallibrary. org/jsource/judaica / ejud_0002_0008_0_08206.html.

The hollow crown: Henry V 2012, television broadcast, BBC Two, 29 December.

The Witherspoon Institute 2008, Marriage and the public good: ten principles, viewed 14 March 2014, http://perma.cc/8XFP-EKH3.

The Witherspoon Institute 2014, Fellows, viewed 14 March 2014, http:winst.org/fellows.

Tribe LH 1993, 'On the edges of life and death', New York Times, 16 May, viewed 21 May 2014, http://www.nyti mes.com/1993/05/16/books/on-the-edges-of-life-an d-death.html.

- ' 'In memoriam: Ronald Dworkin', (Harvard Law Review 2013), vol. 127, pp. 507-510.

Waldron J, review of Religion without God, by R Dworkin, (Boston University Law Review 2014), vol. 94, p. 1207.

Warikoo D 2013, 'Detroit-Area Catholic leaders urge gay marriage supporters to skip communion, Detroit Free Press, 9 April, viewed 21 May 2014, http://www. freep.com/article/20130408/NEWS05/304080041/ Detroit-area-Catholic-leaders. 
LINDA C. MCCLAIN

\section{LEGISLATION}

New York State Senate, Regulatory Session, Open Legislation (June 24, 2011) (transcript archived at http:// perma.cc/656E-3PUV) (statement of Sen. Ruben Diaz).

\section{LEGAL AUTHORITIES}

Bostic v. Rainey [2014] 970 F. Supp. 2d 456.

Brief for Robert P. George et al. as Amicus Curiae in Support of Respondents, Hollingsworth v. Perry [2012] 133 S. Ct. 786 (2012); United States v. Windsor [2013] 133 S. Ct. 2675 (No. 12-307), 2013 WL 390984.

Brief of the Institute for Reproductive Health Access et al. as Amici Curiae in Support of Respondents, Gonzales v. Carhart [2007] 550 U.S. 124 (Nos. 15-1382 \& 05-380), 2006 WL 2736633

Brief of Sandra Cano, The Former 'Mary Doe' of Doe v. Bolton et al. as Amici Curiae in Support of Petitioner, Gonzales v. Carhart [2007] 550 U.S. 124, 159 (2007) (No. 05-380), 2006 WL 1436684).

Brown v. Buhman [2013] 947 F. Supp. 2d 1170.

Bowers v. Hardwick [1986] 478 U.S. 186.

De Leon v. Perry [2014] 2014 WL 715741 [online]. Available from: Westlaw.

DeBoer v. Snyder [2014] 973 F. Supp. 2d 757.

Elane Photography v. Willock [2013] 284 P.3d 428.

Goodridge v. Department of Public Health [2003] 798 N.E.2d 941.

Gonzales v. Carhart [2007] 550 U.S. 124.

Griswold v. Connecticut [1965] 381 U.S. 479. 